\title{
KENNEDY, KENNEDY, AND THE EIGHTH AMENDMENT: "STILL IN SEARCH OF A UNIFYING PRINCIPLE”?
}

\author{
Susan Raeker-Jordan*
}

\begin{abstract}
In Kennedy $v$. Louisiana, the United States Supreme Court held unconstitutional a state law that provided for the imposition of death upon one convicted of raping, but not killing or attempting to kill, a child. Justice Anthony Kennedy wrote the opinion for the Court, in which the majority, employing various analytical tools, brought its "own judgment" to bear on the excessiveness, and therefore the constitutionality, of the death sentence under the Eighth Amendment's Cruel and Unusual Punishments Clause. In emphasizing the Court's use of its own judgment in making the determination of excessiveness or disproportionality, Justice Kennedy and the majority risked the same public and internal dissenting Court criticisms that accompanied previous death penalty opinions in which Court majorities and pluralities similarly employed their own judgments. In the sharp divide over these issues, critics have accused those jurists of disguising their personal views of morality as the doctrinal application of their "own judgment" on these questions. This article argues that despite the criticisms and despite the Court's statement that at least some of its capital punishment case law is "still in search of a unifying principle," there is a precedential thread unifying and justifying the Court's own assessment of excessiveness under the Eighth Amendment. Historical analysis of the Court's Eighth Amendment statements shows that the clear thread in the cases is respect for human dignity and restraint, which plays out through the Amendment's proportionality guarantee. The Court's application of that guarantee against excessiveness has, time and again,
\end{abstract}

\footnotetext{
* Professor of Law, Widener University School of Law, Harrisburg, Pennsylvania. The author would like to thank David Raeker-Jordan for helpful comments on earlier drafts, Tricia Lontz for her thorough research assistance, and Widener University School of Law for research support.
} 
U N I V E R I T Y O F P I T T S B U R G H L A W R E V I E W

\begin{tabular}{l|lll|lllllllll}
\hline P A G E & $\mathbf{1}$ & $\mathbf{0}$ & $\mathbf{8}$ & $\mathrm{V}$ O L U M E & 7 & 3
\end{tabular}$\left(\begin{array}{llll}2 & 0 & 1 & 1\end{array}\right)$

invoked the Court's own judgment, based on contemporary knowledge of punishment, of punishment's goals, and about decency in punishment. This article argues that that approach is sound and historically rooted, and that the Court should continue to apply its own judgment about decency, excessiveness, and proportionality, despite criticisms from the Court's conservative members about personal predilections. 
K E N N D Y, KENNEDY, A N D T H E E I G H H A M E N M E N T

\begin{tabular}{l|lll}
$P$ & A G E & $\mathbf{1} 0$
\end{tabular}

Table of Contents

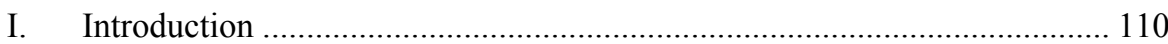

II. Early Statements on the Substantive Limits Imposed by the Cruel and Unusual Punishments Clause.

A. The Seeds of the Current Construct: Eighth Amendment Cases

Pre-Incorporation 112

B. The Seeds of the Current Construct: From Trop v. Dulles to Gregg v. Georgia .................................................................... 121

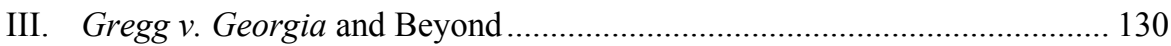

A. A Plurality Reconstructs (or Misconstructs?) Eighth Amendment Doctrine................................................................................ 130

B. Tensions Emerge in Non-Death Penalty Cases ............................... 138

C. Post-Gregg Capital Cases................................................................. 143

D. The Construct Is Rearranged........................................................ 145

IV. Justice Kennedy's Kennedy Opinion ..................................................... 149

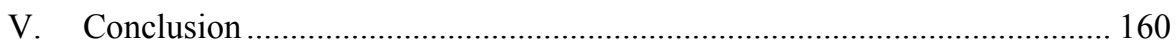


U N I V E R S I T Y O F P I T T S B U R G H L A W R E V I E W

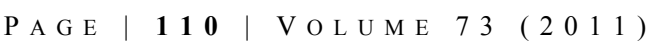

\section{INTRODUCTION}

In Kennedy $v$. Louisiana, the United States Supreme Court held unconstitutional a state law that provided for the imposition of death upon one convicted of raping, but not killing or attempting to kill, a child. ${ }^{1}$ Justice Anthony Kennedy wrote the opinion for the five-member majority and again waded into the Eighth Amendment morass. Despite the public thrashing he has received on other occasions for his death penalty opinions, ${ }^{2}$ his opinion in Kennedy stayed the course. But his opinions have not only been attacked in the public square, they have been vigorously criticized within the Court. In the sharp divide over these issues, one side has accused the other of deciding cases on the basis of its own personal views under the guise of the Court's "own judgment." There may be some evidence to support that view. ${ }^{3}$ But I have also concluded that other members of the Court, even those hurling the accusations at Justice Kennedy, are themselves subject to the same charge. ${ }^{4}$ The impetus for the present article is the majority's approach to resolving the Kennedy case, and the Court's statement that at least some of its case law is "still in search of a unifying principle."

Close examination of the rhetoric of Kennedy could lead one to apply Justice Kennedy's observation to much of the Court's current Eighth Amendment death penalty jurisprudence. But historical analysis of the Court's Eighth Amendment statements shows that there is indeed a unifying thread of respect for human dignity and restraint, which plays out through the Amendment's proportionality guarantee. The Court's application of that guarantee against excessiveness has invoked the Court's own judgment, based on contemporary knowledge of punishment and its

\footnotetext{
${ }^{1} 554$ U.S. 407 (2008).

${ }^{2}$ See Susan Raeker-Jordan, Impeachment Calls and Death Threats: Assessing Criticisms of the Death Penalty Jurisprudence of Justices Kennedy and O'Connor, 52 WAYNE L. REV. 1127, 1128-30 \& nn.110 (2006).

${ }^{3}$ See id. at 1147-72, 1174-77, 1179-80.

${ }^{4}$ See, e.g., Susan Raeker-Jordan, Parsing Personal Predilections: A Fresh Look at the Supreme Court's Cruel and Unusual Death Penalty Jurisprudence, 58 ME. L. REV. 99, 113-15, 124-26 (2006) (making the case against Justice Scalia). It is becoming clearer that justices' ideologies and personal views influence their opinions. See Adam Liptak, The Roberts Court: A Sign of the Court's Polarization: Choice of Clerks, N.Y. TimES, Sept. 6, 2010, at A1, available at http://www.nytimes.com/2010/09/07/ us/politics/07clerks.html?pagewanted $=1 \&$ tntemaill $=$ y\&_r $=1 \&$ emc $=$ tnt.

${ }^{5}$ Kennedy, 554 U.S. at 437. Justice Kennedy seemed to be referring to the procedural aspects of the Court's Eighth Amendment case law, while the Kennedy opinion itself addressed a substantive Eighth Amendment restriction.
} 
goals and contemporary ideas about decency in punishment. ${ }^{6}$ Because that is a sound and historical approach, the Court should continue to apply its own judgment about decency, excessiveness, and proportionality, despite criticisms from the Court's conservative members about personal predilections.

This article will explain the Court's earlier cases, uncovering the unifying theme of restraint and proportionality and assessing Justice Kennedy's Kennedy opinion in that light. Part II will therefore examine the Supreme Court's statements $^{7}$ on the Cruel and Unusual Punishments Clause from the time of Reconstruction until 1910 in Weems v. United States ${ }^{8}$ and through the significant 1958 case of Trop v. Dulles. ${ }^{9}$ That analysis will reveal that the Court has employed essentially two kinds of proportionality review: absolute proportionality and comparative proportionality. This article identifies "absolute proportionality" primarily as the measurement of the seriousness of the crime in relation to the harshness of the penalty to determine if the punishment is simply too much for the crime. "Comparative proportionality" designates those instances in which the Court evaluates a punishment in relation to the practices in other jurisdictions, reflected primarily by the so-called objective indicator of state legislative enactments, to determine if a type of punishment is unusual or too much in comparison. The analysis will reveal that the dominant focus of the Court early on and into the twentieth century was on absolute proportionality, which required it to use its own judgment about what constituted too much punishment. Part III will discuss how Gregg v. Georgia ${ }^{10}$ changed that Eighth Amendment jurisprudence and will address the various developments since. Part IV will then explain Justice Kennedy's approach in Kennedy, analyze it in light of the historical Eighth Amendment approach, and define the unifying theory before concluding in Part V.

\footnotetext{
${ }^{6}$ This article attempts to demonstrate a historical thread justifying and explaining the Court's employment of its own judgment about excessiveness of sentences, and as such, analysis of proportionality theory or the proper components informing the Court's own judgment is beyond the scope of this article. For samples of that literature, see Richard S. Frase, Excessive Prison Sentences, Punishment Goals, and the Eighth Amendment: "Proportionality" Relative to What?, 89 MINN. L. REV. 571 (2005); Youngjae Lee, The Constitutional Right Against Excessive Punishment, 91 VA. L. REV. 677 (2005); Stephen T. Parr, Symmetric Proportionality: A New Perspective on the Cruel and Unusual Punishment Clause, 68 TenN. L. Rev. 41, 59-64 (2000); Herbert L. Packer, Making the Punishment Fit the Crime, 77 HARV. L. REV. 1071 (1964).

${ }^{7}$ I call these "statements" because some were dicta, in cases predating the application of the Eighth Amendment to state punishments.

${ }^{8} 217$ U.S. 349 (1910).

9356 U.S. 86 (1958).

${ }^{10} 428$ U.S. 153 (1976) (plurality opinion).
} 
U N I V E R I T Y O F P I T T S B U R G H L A W R E V I E W

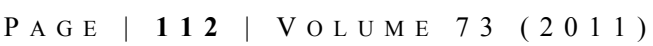

\section{EARly Statements ON THE SUbSTantive Limits IMPOSED BY The CRUEl ANd UNUSUAl PUNishments Clause}

\section{A. The Seeds of the Current Construct: Eighth Amendment Cases Pre-Incorporation}

The Eighth Amendment to the United States Constitution prohibits excessive fines and cruel and unusual punishments. ${ }^{11}$ The meaning of the phrase "cruel and unusual punishments" has proved somewhat difficult to discern. There was scant debate about the Clause at the time of ratification, ${ }^{12}$ and there were few cases presenting the issue in the federal courts. ${ }^{13}$ The few early cases that reached the Court on challenges to the nature of a punishment, and therefore may have required an examination of the clause's meaning, did not discuss the meaning fully because they challenged state punishments to which the Eighth Amendment did not yet apply. ${ }^{14}$ To the extent the Court examined the clause, its focus was on the substantive limits, rather than procedural requisites, compelled by the Eighth Amendment. What an examination of those early cases reveals is a clear tendency of the Court to measure a punishment for excessiveness, to state in so many words that a punishment is or is not simply too much for the crime involved. The unmistakable flavor of the opinions, even when in dicta, manifests the Court's approval of or revulsion at the degree of a penalty, in many instances relying for that reaction on nothing more than the justices' own perceptions about proportionality.

\footnotetext{
${ }^{11}$ U.S. CONST. amend. VIII (providing that "[e]xcessive bail shall not be required, nor excessive fines imposed, nor cruel and unusual punishments inflicted"). The Court has held that the Eighth Amendment applies to the states through the Fourteenth Amendment's Due Process Clause. Robinson v. California, 370 U.S. 660,667 (1962).

${ }^{12}$ See Weems v. United States, 217 U.S. 349, 368 (1910).

${ }^{13}$ See, e.g., id. at 369 (observing in 1910 that "[n]o case has occurred in this court which has called for an exhaustive review"); $i d$. at 400 (White, J., dissenting) ("[I]n most of the cases in which the protection of the Amendment has been invoked the cases came from courts of last resort of States ....").

${ }^{14}$ See Pervear v. Commonwealth, 72 U.S. (5 Wall.) 475, 479-80 (1866); see also Collins v. Johnston, 237 U.S. 502, 510-11 (1915); Weems v. United States, 217 U.S. 349, 400 (1910) (White, J., dissenting) (" $[I] n$ most of the cases in which the protection of the Amendment has been invoked the cases came from courts of last resort of States, and the opinions leave room for the contention that they proceeded upon the implied assumption that the Eighth Amendment did not govern the States by virtue of the adoption of the Fourteenth Amendment.”); Howard v. Fleming, 191 U.S. 126, 136 (1903); O’Neil v. Vermont, 144 U.S. 323, 332 (1892); McElvaine v. Brush, 142 U.S. 155, 158 (1891); In re Kemmler, 136 U.S. 436, 446, 447-48 (1890).
} 
To begin, in 1866, despite the fact that it did not yet review state punishments under the clause, ${ }^{15}$ the Court in Pervear $v$. Commonwealth considered a punishment for the unlicensed keeping of an establishment for the illegal keeping and sale of liquor. ${ }^{16}$ The Court stated:

[I]t appears from the record that the fine and punishment in the case before us was fifty dollars and imprisonment at hard labor in the house of correction for three months. We perceive nothing excessive, or cruel, or unusual in this. The object of the law was to protect the community against the manifold evils of intemperance. The mode adopted, of prohibiting under penalties the sale and keeping for sale of intoxicating liquors, without license, is the usual mode adopted in many, perhaps, all of the States. It is wholly within the discretion of State legislatures. ${ }^{17}$

The Court's brief consideration reveals that, as early as 1866, it was conducting proportionality analysis. First, the Court itself assessed the punishment for excessiveness, ${ }^{18}$ measuring it against the severity of the crime (the "manifold evils of intemperance"). A natural reading of the two important sentences on this score essentially reads them as one: "[w]e perceive nothing excessive, or cruel, or unusual in this [because t] he object of the law was to protect the community against the manifold evils of intemperance." The "manifold evils of intemperance" implicitly justified the amount of the punishment in the perception of the justices. The quotation is also lexically significant, in that the justices used the word "perceive," which commonly means to "[t]ake in with the mind or senses" 19 and had no different meaning in $1866 .^{20}$ The perception of the justices, apparently

${ }^{15}$ Indeed, the Court acknowledged that fact but proceeded to analyze the issue anyway: "[o]f this proposition it is enough to say that the article of the Constitution relied upon in support of it does not apply to State but to National legislation. But if this were otherwise the defence could not avail the plaintiff in error. ..." Pervear, 72 U.S. (5 Wall.) at 479-80.

${ }^{16} I d$.

${ }^{17} I d$.

${ }^{18}$ The Court confirmed this observation in Weems v. United States, 217 U.S. 349, 369 (1910), when, in discussing Pervear, it stated, "we ... said that we perceive nothing excessive, or cruel and unusual in a fine for fifty dollars and imprisonment at hard labor in the house of correction for three months, which was imposed for keeping and maintaining, without a license, a tenement for the illegal sale and illegal keeping of intoxicating liquors."

${ }^{19} 2$ THE NEW SHORTER OXFORD ENGLISH DiCTIONARY 2155 (1993).

${ }^{20}$ See NoAh Webster, A Dictionary of the English Language 730 (10th ed. 1866) (defining "perceive" as follows: "1. To have knowledge or receive impressions of external objects through the 
gleaned from nothing but their own knowledge and experience, was that this was not too much punishment in response to this crime. One might call such an assessment one of absolute proportionality: the bottom line is that the amount of the punishment fits (or does not fit) the crime. But the Court went further, still, to consider the type ${ }^{21}$ of punishment for the crime (penalties and fines), at which point it compared the punishment to other states' practices or punishments. The comparison revealed nothing out of line in the state's punishment in relation to other states' practices. One might call this determination one of comparative proportionality: this punishment is not unusual when compared with what others are imposing for this crime. So while the Court was not calling its review any sort of proportionality analysis, it unmistakably conducted both an absolute and a comparative proportionality or excessiveness analysis.

In Wilkerson v. Utah, ${ }^{22}$ the Court had what seems to have been its first opportunity to interpret the Amendment in a case to which it applied. At the time of the case, Utah was a Territory, not yet a state, ${ }^{23}$ and its legislative power was subject to the limitations of the federal Constitution, including the Cruel and Unusual Punishments Clause. ${ }^{24}$ The defendant had been sentenced to death by shooting. ${ }^{25}$ Stating that it was difficult to define exactly what the Amendment meant, the Court thought it safe to conclude that torturous punishments were forbidden by the Clause. ${ }^{26}$ Because the challenge was not to the severity of execution itself but rather to execution by shooting, the Court, in upholding the punishment, confined its analysis to that type of execution. In so doing, it referred

medium or instrumentality of the senses or bodily organs. 2. To have mental knowledge of. 3. To be affected by; to receive impressions from"), available at http://books.google.com/books?id=K18IAAAA QAAJ\&dq=a\%20dictionary\%20of $\% 20$ the $\% 20$ english $\% 20$ language $\% 20$ webster $\% 201866 \& p g=P A 730 \#$ $\mathrm{v}=$ onepage $\& \mathrm{q} \& \mathrm{f}=$ false.

${ }^{21}$ Indeed, at least the way the Court described it, the defendant's claim was that $a$ fine, rather than the particular amount imposed, was cruel and unusual. See Pervear, 72 U.S. at 479 ("The third proposition of the plea is that fines and penalties imposed and inflicted by the State law for offences charged in the indictment are excessive, cruel, and unusual.").

2299 U.S. 130 (1878).

${ }^{23}$ Utah became a state on January 4, 1896. Utah Statehood, UTAH.COM, http://www.utah.com/visitor/ state_facts/statehood.htm (last visited Sept. 9, 2011).

${ }^{24}$ Wilkerson, 99 U.S. at 133.

${ }^{25} \mathrm{Id}$. at 131.

${ }^{26}$ Id. at $135-36$. 
to many other instances when criminals had been sentenced to be shot. ${ }^{27}$ As in Pervear, when addressing the mode of punishment, the Court seemed to compare it to other practices to determine its propriety, conducting a comparative proportionality analysis. It also excluded shooting from the category of torture. ${ }^{28}$ But in this case, the Court did not determine if execution itself was too much punishment- that is, it did not conduct an absolute proportionality analysisbecause the challenge was not to the amount of punishment or to the severity of the death sentence itself, but to the method of its implementation. ${ }^{29}$

${ }^{27}$ See id. at 134-35 ("Cruel and unusual punishments are forbidden by the Constitution, but the authorities referred to are quite sufficient to show that the punishment of shooting as a mode of executing the death penalty for the crime of murder in the first degree is not included in that category, within the meaning of the eighth amendment.") (emphasis added).

${ }^{28}$ See id. at 136.

${ }^{29}$ In the 1890 case of In re Kemmler, 136 U.S. 436 (1890), the Court similarly added meaning to the torture-banning aspects of the clause but otherwise did not further our understanding of the proportionality aspects of the Eighth Amendment because the defendant had again only challenged the mode of the punishment, not its amount. See id. at 441-42 ("[C]ounsel for the petitioner offered to prove that the infliction of death by the application of electricity as directed is a cruel and unusual punishment, within the meaning of the constitution .... [A]nd upon that evidence it was argued that the punishment in that form was cruel and unusual within the inhibition of the constitutions of the United States and of the State of New York, and that therefore the act in question was unconstitutional.") (emphasis added) (internal quotation omitted). The Court itself would later say that the torture language in Kemmler "was not meant ... to give a comprehensive definition of cruel and unusual punishment ...." Weems v. United States, 217 U.S. 349, 370-71 (1910).

After Kemmler, but before the 1903 Howard case, Howard v. Fleming, 191 U.S. 126 (1903), the Court was presented with punishment cases charging a host of constitutional violations, most predominantly due process, double jeopardy, and equal protection violations, but also including cruel and unusual punishment for good measure. See, e.g., Moore v. Mo., 159 U.S. 673 (1895); McDonald v. Mass., 180 U.S. 311 (1901). Defendants in these cases were given enhanced punishments for subsequent offenses. While the Court stated that it found no cruel and unusual punishment (or any other constitutional violations, for that matter), it focused most of its attention on due process and dashed off the cruel and unusual punishment determination in a sentence at the end of the cases. Nonetheless, to the extent that they addressed considerations also relevant to cruel and unusual punishment challenges, these discussions not only make comparisons to other state punishment practices (thereby engaging in comparative proportionality analysis) but also note that these more severe punishments were justified because the defendants were more culpable as repeat offenders (thereby engaging in absolute proportionality analysis). In essence, the punishments were not too much, or disproportional, for these crimes. Thus, the Court in both cases used objective, comparative evidence but also conducted its own examination of absolute excessiveness or proportionality. See Moore, 159 U.S. at 677 ("[T]he punishment for the second is increased, because by his persistence in the perpetration of crime, he has evinced a depravity, which merits a greater punishment, and needs to be restrained by severer penalties than if it were his first offence.") (quoting another source); McDonald, 180 U.S. at 312 ("The statute ... is aimed at habitual criminals; and simply imposes a heavy penalty upon conviction of a felony committed ... by one who had been twice convicted and imprisoned for crime .... The punishment is for the new crime only, but is the heavier if he is an habitual criminal."). 
The Court decided O'Neil v. Vermont ${ }^{30}$ in 1892, but the case is only significant in Eighth Amendment jurisprudence because of the dissent by Justice Field, cited by the Supreme Court in the later important case of Weems v. United States. ${ }^{31}$ The majority opinion in O'Neil did not address the Eighth Amendment issue, noting that the defendant did not raise it before the Supreme Court and that, in any event, the Amendment did not apply to state punishments. ${ }^{32}$ Justice Field's dissent, however, concurred in by Justices Harlan and Brewer, recognized that the Eighth Amendment is concerned with the severity of punishments:

The inhibition is directed, not only against punishments of the character mentioned, but against all punishments which by their excessive length or severity are greatly disproportioned to the offences charged. The whole inhibition is against that which is excessive either in the bail required, or fine imposed, or punishment inflicted. ${ }^{33}$

It is instructive to note Justice Field's application of this principle to the case under consideration, which is captured in the following quotation:

Fifty-four years' confinement at hard labor, away from one's home and relatives, and thereby prevented from giving assistance to them or receiving comfort from them, is a punishment at the severity of which, considering the offences [of multiple sales of intoxicating liquor without authority], it is hard to believe that any man of right feeling and heart can refrain from shuddering. ${ }^{34}$

Justice Field and the two joining justices were applying their own perceptions and "right feelings and heart[s]," leading them to conclude that the fifty-four year sentence was simply too much in relation to the crime of multiple liquor sales. The dissenting justices, in interpreting the Cruel and Unusual Punishments Clause, applied their own judgment about the absolute excessiveness of the punishment under the Eighth Amendment. This excessiveness interpretation is consistent with the 1866 Pervear case and later cases into the 21 st century.

\footnotetext{
${ }^{30} 144$ U.S. 323 (1892).

${ }^{31} 217$ U.S. 349, 371 (1910).

${ }^{32} 144$ U.S. at $331-32$.

${ }^{33} I d$. at 339-40 (Field, J., dissenting).

${ }^{34} \mathrm{Id}$. at 340 (emphasis added).
} 
Eleven years after O'Neil v. Vermont, the Court decided Howard v. Fleming. ${ }^{35}$ The defendants there were convicted of conspiracy to defraud and challenged their sentences for terms of ten and seven years, respectively, in the penitentiary, "in that the sentence was more severe than ever before inflicted in [the state] for a like offense, and was cruel and unusual ...."36 The Court did not apply the Eighth Amendment because it still did not apply to state punishments; the defendants had to challenge their sentences under the Equal Protection Clause. ${ }^{37}$ But the Court did give some contours to the concept of cruelty and unusualness in addressing the equal protection challenges. The defendants were clearly objecting to the excessive nature of the sentence, so the Court's response is instructive.

The Court first stated that a punishment is not cruel because it is a more severe punishment than has been given for what most people would say are even more serious crimes than the one at issue. ${ }^{38}$ It also stated, however, that "[s]windling by means of a pretended gold brick is no trifling crime, and a conspiracy to defraud by such means does not commend itself to sympathy or leniency. ${ }^{, 39}$ The Court used its own judgment in measuring both the seriousness of the crime ("swindling ... is no trifling crime") and the punishment's severity, determining that this punishment was not too much for this crime of fraud: "It is enough ... to say that a sentence of ten years for an offense of [conspiracy to defraud and swindling] ... does not seem to us deserving to be called cruel. ${ }^{40}$ The Court's words are of absolute proportion, comparing the severity of the sentence to the seriousness of the crime. It did not compare the sentence to other states' punishment practices for this crime, perhaps because the challenge was clearly to the severity of the punishment and not to its type. Rather, the Court simply assessed whether these terms of years were too much, excessive, or cruel in an absolute sense. In short, it conducted an absolute proportionality analysis. Just as important, the Court's chosen words are again instructive, demonstrating the

35191 U.S. 126 (1903).

${ }^{36} I d$. at 135 . Two defendants were sentenced to ten years in the penitentiary and the third was given seven years for "swindling" by trying to pass off a brick as gold. Id. at 135-36.

${ }^{37} I d$. at 135.

${ }^{38} I d$. at 135-36. Although the Court compared the punishment for this crime with punishment for other crimes, and thus one might consider it a comparative proportionality analysis, its focus was on excessiveness, as demonstrated by the discussion in the text above. See infra text accompanying notes $39-42$.

${ }^{39}$ Id. at 136.

${ }^{40} I d$. (emphasis added). 
method employed to reach its result: the punishment did not "seem to [them] deserving" of the cruelty label. ${ }^{41}$ The justices' perception, sense, own judgmentwhatever one wants to call it-was simply that the punishment was not too much for this crime. To this point, then, the Court continued to use its own sense of excessiveness when facing a challenge to the amount of a punishment under the Eighth Amendment. ${ }^{42}$

Seven years later, the Court decided Weems $v$. United States, ${ }^{43}$ a case significant for its exhaustive examination of the meaning of the Cruel and Unusual Punishments Clause. ${ }^{44}$ The case clearly raised an excessiveness challenge to the defendant's punishment, ${ }^{45}$ the cadena temporal, ${ }^{46}$ which consisted of fifteen years at hard labor, a fine, and other "accessories" of punishment" for the crime of

${ }^{41} I d$. (emphasis added).

${ }^{42}$ One could argue that the Court also threw a sort of deterrence analysis into its proportionality mix, stating in the same paragraph with the cruelty discussion that "[i]f the effect of this sentence is to induce like criminals to avoid its territory, [the state] is to be congratulated, not condemned." Id. The Court, in later Eighth Amendment cases, will formally employ deterrence considerations in assessing excessiveness of punishment. See infra text accompanying notes 132-33, 208, 241-44. See also Stanford v. Kentucky, 492 U.S. 361, $403-05$ (1989) (Brennan, J., dissenting); Penry v. Lynaugh, 492 U.S. 302, 335-36 (1989) (opinion of O’Connor, J.), abrogated by Atkins v. Virginia, 536 U.S. 304 (2002); Thompson v. Oklahoma, 487 U.S. 815, 836-38 (1988) (plurality opinion); Enmund v. Florida, 458 U.S. 782, 798-800 (1982).

${ }^{43} 217$ U.S. 349, 370-71 (1910). Some date the Court's proportionality principle to this case. See, e.g., Harmelin v. Michigan, 501 U.S. 957, 996 (1991) (Kennedy, J., concurring in part and concurring in the judgment) (stating that "stare decisis counsels our adherence to the narrow proportionality principle that has existed in our Eighth Amendment jurisprudence for 80 years" and that "[w]e first interpreted the Eighth Amendment to prohibit 'greatly disproportioned' sentences in Weems v. United States" (citations and other internal quotation omitted)). But as I have shown, the Court recognized the principle well before Weems.

${ }^{44}$ The Eighth Amendment did not technically apply in this case of a challenged punishment under Philippine law barring cruel and unusual punishments, but the Court said the Philippine clause was taken from our Bill of Rights and "must have the same meaning." Weems, 217 U.S. at 367. The case came to the United States Supreme Court from the Supreme Court of Philippines, id. at 357, because in 1910 the United States still occupied and administered the Philippines. See Background Note: Philippines, U.S. DEP’T OF STATE, http://www.state.gov/r/pa/ei/bgn/2794.htm (June 3, 2011).

${ }^{45}$ The defendant claimed the amount of the fine and length of imprisonment was cruel and unusual. 217 U.S. at 362 .

${ }^{46}$ See id. at 363 .

${ }^{47}$ The law also required, for the term of imprisonment, "a chain at the ankle and wrist of the offender, hard and painful labor, no assistance from friend or relative, no marital authority or parental rights or rights of property ...." Id. at 366. After imprisonment, the offender was still subject to "a perpetual limitation of his liberty. He is forever kept under the shadow of his crime, forever kept within voice and view of the criminal magistrate, not being able to change his domicil without giving notice to the 
falsifying a public document. ${ }^{48}$ The Court's opinion is replete, in various phrasings, with references to what this article calls absolute proportion. At the outset, the Court expressed "wonder" at the sentence, effected in "minds accustomed to a more considerate adaptation of punishment to the degree of crime." expressed amazement at the gravity of the penalty and articulated the oft-quoted belief that "it is a precept of justice that punishment for crime should be graduated and proportioned to offense." ${ }^{, 50}$ It also recounted its decision in 1866 in Pervear $v$. Commonwealth ${ }^{51}$ in which "[the Court] ... said that [it] perceive[d] nothing excessive" in the punishment in that case. ${ }^{52}$ The Weems Court majority also specifically referenced the opinion of Justices Field, Harlan, and Brewer in $O^{\prime} N e i l$ v. Vermont ${ }^{53}$ in which Justice Field stated that the Eighth Amendment is directed "against all punishments which by their excessive length or severity are greatly disproportioned to the offences charged. The whole inhibition is against that which is excessive either in the bail required, or fine imposed, or punishment inflicted. $" 54$ In discussing the Framers' intent, the Court opined that the founders surely meant not only to limit the torturous British punishments but also to limit legislatures' power to fix cruelly excessive punishments. ${ }^{55}$ The Court was clearly concerned about the infliction of too much punishment.

After detailed consideration, the Weems Court determined that the penalty at issue constituted cruel and unusual punishment. ${ }^{56}$ It found that both the length of the sentence and the extent of the accessory punishments were excessive as well as

\footnotetext{
'authority immediately in charge of his surveillance,' and without permission in writing." Id. Another accessory was "perpetual absolute disqualification," which was defined as "the deprivation of office, even though it be held by popular election, the deprivation of the right to vote or to be elected to public office, the disqualification to acquire honors, ... and the loss of retirement pay ...." Id. at 364-65. For a fuller description of such "accessories," see generally $i d$.

${ }^{48} I d$. at $357-58$.

${ }^{49} I d$. at 365 (emphasis added).

${ }^{50} I d$. at 367.

${ }^{51} 72$ U.S. 475 (5 Wall.) (1866).

52217 U.S. at 369 . Use of the word "perceive" in regard to the excessiveness determination constitutes the Court's acknowledgment that it employs its own judgment in making that assessment.

${ }^{53} I d$. at 371 (citing O’Neil v. Vermont, 144 U.S. 323 (1892)).

${ }^{54} 144$ U.S. at 339-40 (Field, J., dissenting).

${ }^{55}$ Weems, 217 U.S. at 372-73.

${ }^{56}$ Id. at $377,381,382$.
} 
unusual, there being no law like it in American jurisdictions. ${ }^{57}$ The opinion here clearly tracks precedent in identifying the amount of the punishment distinctly from the type of punishment. But most of the opinion centers on the degree or amount of the punishment, with the Court only buttressing its excessiveness determination with the observation that there were worse crimes, like certain homicides and many others, that were not punished as severely. ${ }^{58}$ In that absolute proportionality assessment, the Court, on its own, judged that this punishment was excessive and, therefore, unjust. ${ }^{59}$ It seemed also to take its analysis a step further, linking the extent of the punishment to its purposes, ${ }^{60}$ an approach that would also show up in later cases. ${ }^{61}$

${ }^{57}$ Id. at 377 (stating that the punishments of the cadena temporal "come under the condemnation of the bill of rights, both on account of their degree and kind") (emphasis added).

${ }^{58} I d$. at 380 (citing examples such as "inciting rebellion, conspiracy to destroy the Government by force, ... robbery, larceny," and others). The Court seemed only to support its independent judgment about the excessiveness of the punishment with comparative evidence that even worse crimes are not punished as severely as the one at issue here. See also Harmelin v. Michigan, 501 U.S. 957, 1005 (1991) (Kennedy, J., concurring in part and concurring in the judgment) (stating that "[i]n ... Weems, [a] decision[] in which the Court invalidated [a] sentence[] as disproportionate, we performed a comparative analysis of sentences after determining that the sentence imposed was grossly excessive punishment for the crime committed"). Although one might also call such support a comparative analysis, comparing the punishment for this crime with punishment for other crimes, it is clear from the following passage that the Court's focus was primarily on its own views of the excessive or disproportionate nature of this punishment:

[T] he highest punishment possible for a crime which may cause the loss of many thousand of dollars ... is not greater than that which may be imposed[, as in this case,] for falsifying a single item of a public account. And this contrast shows more than different exercises of legislative judgment. ... It condemns the sentence in this case as cruel and unusual. It exhibits a difference between unrestrained power and that which is exercised under the spirit of constitutional limitations formed to establish justice.... The purpose of punishment is fulfilled, crime is repressed by penalties of just, not tormenting, severity, its repetition is prevented, and hope is given for the reformation of the criminal.

Weems, 217 U.S. at 381 (emphasis added). The Court's own view was that the cadena temporal was too much punishment for the crime of falsifying a public document, and that judgment was reinforced by the recognition that other, more serious crimes were not punished so harshly.

${ }^{59} I d$. at 381 (stating that this punishment "exhibit[ed] a difference between unrestrained power and that which is exercised under the spirit of constitutional limitations formed to establish justice").

${ }^{60} \mathrm{Id}$. (stating that " $[\mathrm{t}] \mathrm{h}$ e purpose of punishment is fulfilled, crime is repressed by penalties of just, not tormenting, severity, its repetition is prevented, and hope is given for the reformation of the criminal").

${ }^{61}$ See, e.g., Stanford v. Kentucky, 492 U.S. 361, $403-05$ (1989) (Brenna, J., dissenting); Penry v. Lynaugh, 492 U.S. 302, 335-36 (1989) (opinion of O’Connor, J.), abrogated by Atkins v. Virginia, 536 
These cases show that early precedents of the Supreme Court roughly marked out the path for assessing whether punishments were cruel and unusual. If the punishments were challenged as excessive for the crime committed, the Court measured the evils of the crime against the harshness of the penalty, assessing for itself whether the punishment was simply too much for the crime-analysis that could be called absolute proportionality. If the challenge were to the mode or type of punishment, in essence arguing that it was cruel and unusual to impose a punishment of this kind for this crime, then the Court would look to other practices - analysis that could be called comparative proportionality. But without doubt, what dominated the early cases was the Court's discussion and assessment of punishments for excessiveness or absolute proportionality.

\section{B. The Seeds of the Current Construct: From Trop v. Dulles to Gregg v. Georgia}

There appears to have been little pertinent Eighth Amendment activity in the Supreme Court ${ }^{62}$ after Weems until the 1958 case of Trop v. Dulles, ${ }^{63}$ in which the defendant was punished under federal law $^{64}$ by denationalization for the crime of wartime desertion. ${ }^{65}$ The Eighth Amendment directly applied. The plurality ${ }^{66}$ began its Eighth Amendment analysis by stating that because desertion could be punished by death, punishment by denationalization did not raise the issue of excessiveness of the punishment in relation to the seriousness of the crime; rather, the question was only "whether this penalty subjects the individual to a fate forbidden by the

U.S. 304 (2002); Thompson v. Oklahoma, 487 U.S. 815, 836-38 (1988) (plurality opinion); Enmund v. Florida, 458 U.S. 782, 798-800 (1982).

${ }^{62}$ There was a smattering of bail cases in which defendants claimed either unconstitutional denial of bail or excessive bail. See Carlson v. Landon, 342 U.S. 524 (1952); Stack v. Boyle, 342 U.S. 1 (1951); Berkman v. U.S., 250 U.S. 114 (1919). The Court's decision in Badders v. United States, 240 U.S. 391 (1916), appeared to address a cruel and unusual punishment question but provided no interpretive guidance. See id. at 394 (stating simply that "there is no ground for declaring the punishment unconstitutional").

${ }^{63} 356$ U.S. 86 (1958). Louisiana ex rel. Francis v. Resweber, 329 U.S. 459 (1947), was decided before Trop v. Dulles but addressed the constitutionality of an electrocution performed after an initial failed attempt at electrocution. The facts are unique and do not assist in assessing the more general doctrinal questions addressed in this article.

${ }^{64}$ The opinion cited to Section 401(g) of the Nationality Act of 1940, 8 U.S.C. $\S 1481$ (a)(8) (2008). 356 U.S. at $88 \&$ n. 1 .

${ }^{65} 356$ U.S. at 87.

${ }^{66}$ Chief Justice Warren wrote an opinion in which Justices Black, Douglas, and Whittaker joined. Id. at 87. Justice Brennan concurred in the judgment. Id. at 105. 
principle of civilized treatment guaranteed by the Eighth Amendment." ${ }^{967}$ How that statement differs from a question of excessiveness - when a punishment is simply too much - is not clear. What is clear is that the plurality was wrong that the case was not about excessiveness; it evaluated the punishment under the Eighth Amendment in just that way.

The plurality began by acknowledging that the Court had never elaborated on the "exact scope" of the phrase in the Eighth Amendment. ${ }^{68}$ The opinion nonetheless determined that the "basic policy" of the Clause was "firmly established in the Anglo-American tradition of criminal justice." ${ }^{.69}$ The entire emphasis of the opinion is on that basic policy idea: "The basic concept underlying the Eighth Amendment is nothing less than the dignity of man. While the State has the power to punish, the Amendment stands to assure that this power be exercised within the limits of civilized standards. ${ }^{, 70}$ It then incorporated the proportionality idea, stating, "[f]ines, imprisonment, and even execution may be imposed depending on the enormity of the crime, but any technique outside the bounds of these traditional penalties is constitutionally suspect." ${ }^{, 71}$ The previous sentence unmistakably contains implications of proportion, recognizing different levels of punishment fit different levels of crime. But its second half also melds in the concept of unusual modes of punishment; any type of punishment outside of what is traditionally done is deserving of special scrutiny, presumably because it is unusual. Consistent with those observations, the plurality used as an example of cruel and unusual punishment the disproportionate and unusual punishment of the cadena temporal in the Weems case. ${ }^{72}$ In this discussion, the Trop plurality implicitly recognized that a punishment could be both excessive and unusual and fail the Eighth Amendment test in both ways. Its discussion also seemed to recognize, however, that a traditional punishment might be excessive and violate the Amendment even if not unusual in the strict sense. ${ }^{73}$ Finally, and to close its explication of the applicable rules, the plurality stated, "the words of the

${ }^{67} I d$. at 99 (majority opinion).

${ }^{68} \mathrm{Id}$.

${ }^{69}$ Id. at $99-100$.

${ }^{70} I d$. at 100 (emphases added).

${ }^{71} I d$. (emphasis added).

${ }^{72} I d$. at 100 .

${ }^{73}$ Indeed, it seems the Court was not as interested in what it meant to be "unusual" under the Amendment. See infra notes 92-93. 
Amendment are not precise, and ... their scope is not static. The Amendment must draw its meaning from the evolving standards of decency that mark the progress of a maturing society.",74

From this paragraph of Trop comes much of present-day Eighth Amendment jurisprudence. ${ }^{75}$ Future opinions are replete with references to the "dignity of man," " civilized standards, and the "evolving standards of decency that mark the progress of a maturing society." "77 What is first striking from a close look at this discussion, however, is the plurality's insistence at the outset that the case is not about excessiveness, since death could be imposed for the crime of desertion (i.e., something short of death surely could not be excessive). Nonetheless, the plurality used Weems, a case about disproportionality and unusualness, to illustrate the constitutional limit placed by civilized standards on the power to punish. So what could the plurality have meant when it said the case was not about excessiveness? Here one might draw a distinction between types of absolute proportionality. Absolute proportionality, as used before in this article, measures the severity of punishment vis-à-vis the seriousness of the crime: a punishment may be too much for the crime committed. Because it is the assessment the Court has most used, we can call it primary absolute proportionality. A second type of absolute proportionality would measure the severity of punishment qua punishment and would examine whether a punishment could be considered absolutely excessive, no matter the crime committed. Because the Court has not employed this type of proportionality analysis very often, we can call it secondary absolute

\footnotetext{
${ }^{74}$ Trop, 356 U.S. at $100-01$.

${ }^{75} \mathrm{Cf}$. John F. Stinneford, The Original Meaning of "Unusual": The Eighth Amendment as a Bar to Cruel Innovation, 102 Nw. U. L. REV. 1739, 1749 (2008) (stating that Trop's evolving-standards-of-decency test "has dominated the Supreme Court's Cruel and Unusual Punishments Clause jurisprudence over the past fifty years"). In later cases, the words used by the Court are the same- but Trop has been misread, and the construct was consequently rearranged, as I will show in the discussion of Gregg v. Georgia, 428 U.S. 153 (1976) (plurality opinion), in Part III.

${ }^{76}$ Later the Court will update the phrase to "dignity of the person" or "dignity of all persons." See Kennedy v. Louisiana, 554 U.S. 407, 420 (2008) ("Evolving standards of decency must embrace and express respect for the dignity of the person ...."); Roper v. Simmons, 543 U.S. 551, 560 (2005) ("By protecting even those convicted of heinous crimes, the Eighth Amendment reaffirms the duty of the government to respect the dignity of all persons."). This article will use the older phrasing when discussing the older cases and the newer phrasing when discussing the newer cases.

${ }^{77}$ See, e.g., Roper v. Simmons, 543 U.S. 551, 560-61 (2005); Atkins v. Virginia, 536 U.S. 304, 311-12 (2002); Penry v. Lynaugh, 492 U.S. 302, 330-31 (1989), abrogated by Atkins v. Virginia, 536 U.S. 304 (2002); Stanford v. Kentucky, 492 U.S. 361, 369 (1989), abrogated by Roper v. Simmons, 543 U.S. 551 (2005); Thompson v. Oklahoma, 487 U.S. 815, 821-22 (1988) (plurality opinion); Gregg v. Georgia, 428 U.S. 153, 173 (1976) (plurality opinion).
} 
proportionality. Thus, in Trop, the plurality could say that the case was not about the excessiveness of denationalization for desertion because desertion could be punished by death; clearly the seriousness of the crime could warrant an even more severe penalty than denationalization. Denationalization could not then be too much punishment in that first, or primary, absolute sense. But the punishment nevertheless might be absolutely excessive as a punishment in the second sense because of its offensiveness in general or categorically to civilized standards; i.e., it is too much punishment to impose on anyone for anything. In that case, the Court engages in a much purer form of proportionality analysis in that it must rely wholly on ideas about morality, human dignity, and what constitutes simply too much punishment. $^{78}$ It relies on those ideas in the primary sense of absolute proportionality, too, because at bottom, excessiveness is about offensiveness to or disrespect of human dignity. The difference is that in the primary absolute proportionality analysis, the Court is, at the same time, weighing the punishment against the seriousness of the offense; there is at least some objective benchmark for saying the punishment is too much: ten years in prison is not too much punishment categorically, but it is too much for jaywalking, a non-serious crime, when it would not be, perhaps, for the much more serious crime of embezzlement. $^{79}$

${ }^{78}$ One could criticize this assessment by arguing that it requires justices to inject their personal preferences into constitutional adjudication. But as the plurality noted in Thompson v. Oklahoma, 487 U.S. 815,833 n.40 (1988):

That the task of interpreting the great, sweeping clauses of the Constitution ultimately falls to us has been for some time an accepted principle of American jurisprudence. See Marbury v. Madison, 1 Cranch 137, 177 (1803) ("It is emphatically the province and duty of the judicial department to say what the law is."). With the Eighth Amendment, whose broad, vague terms do not yield to a mechanical parsing, the method is no different.

A discussion of the proper components informing the Court's own judgment is beyond the scope of this article.

${ }^{79}$ Arguably even less pure is a comparative excessiveness analysis, in which the Court may measure a punishment against the punishments of other jurisdictions to help it to determine if the punishment seems to be too much. In that situation, though, the Court could be comparing potentially equally harsh punishments for the same crimes, across jurisdictions. The problem with comparative excessiveness is that it is not necessarily limiting; many state legislatures could impose an inhumane punishment, but as long as enough states imposed it, the punishment would then not be "excessive" under the chosen analysis. The only limit on harshness or excessiveness would be the imaginations of other state legislatures in their punishments, which, taken to the logical extreme, could be no limit at all.

The propriety of conducting comparative proportionality analysis implicates ideas about majoritarian rule against individual rights. If many legislatures, the people's representatives, choose a particular punishment, then, the argument goes, it cannot be cruel and unusual because so many 
The preceding distinction explains the plurality's approach to the punishment in Trop. As the plurality proceeded to describe the punishment of denationalization, it did not describe the punishment in the first, or primary, sense discussed above, in relation to the crime of wartime desertion. Rather, it described the punishment even more absolutely, in the second sense, and in a parade of horribles. Relying on the "dignity of man" principle, the plurality first concurred in the view of the dissenter in the decision below, Chief Judge Clark, who wrote, "[i]n my faith, the American concept of man's dignity does not comport with making even those we would punish completely 'stateless' ...." ${ }^{80}$ These words make clear that the plurality thought the punishment was excessive in the second absolute sense: even if some punishment is warranted, no crime warrants this extreme punishment. Much of the content given to the concept of human dignity is captured by the plurality's general revulsion at the penalty as a penalty:

We believe, as did Chief Judge Clark in the court below, that use of denationalization as a punishment is barred by the Eighth Amendment. There may be involved no physical mistreatment, no primitive torture. There is instead the total destruction of the individual's status in organized society. It is a form of punishment more primitive than torture, for it destroys for the individual the political existence that was centuries in the development ....

This punishment is offensive to cardinal principles for which the Constitution stands. It subjects the individual to a fate of ever-increasing fear and distress. ${ }^{81}$

Clearly the plurality thinks the punishment is simply too much, simply excessive. Further analysis of Chief Judge Clark's dissent in the court below supports the conclusion that the plurality employed the second type of absolute excessiveness or proportionality analysis.

Chief Judge Clark's dissent itself explicitly incorporated by reference the arguments about the cruel and unusual nature of punitive expatriation in a Yale Law Journal comment analyzing that punishment contained in the Expatriation Act of

jurisdictions approve of the punishment. The counter to that argument is that if majoritarian preferences governed in every case, there would be no room left for individual rights protections under the Constitution; individuals' rights would be protected only insofar as the majority, not the Constitution, determined.

${ }^{80}$ Trop, 356 U.S. at 101 n.33 (quoting Trop v. Dulles, 239 F.2d 527, 530 (2d Cir. 1956) (Clark, C.J., dissenting), rev'd, 356 U.S. 86 (1958)) (emphasis added).

${ }^{81} I d$. at 101-02 (footnote omitted). 
PAGE | 1226 | V O L U M E $\left.73 \begin{array}{lllll}2 & 0 & 1 & 1\end{array}\right)$

1954. ${ }^{82}$ In that comment, the author's Eighth Amendment discussion centered primarily on the proportionality of expatriation as punishment for crime. ${ }^{83}$ First setting out tests for "cruelty" under the Amendment, ${ }^{84}$ the author stated, "[i]t is . . clear that punishments overly severe in relation to the seriousness of the offense are proscribed. ${ }^{, 85}$ Later the author drew the same distinction drawn by the Trop plurality, around what this article has described as the primary and secondary types of absolute proportionality:

Certainly it could not reasonably be contended that denationalization is a penalty disproportionate to the remaining crimes for which it is presently imposed. If loss of citizenship can be imposed at all as punishment for crime, it would seem a reasonable penalty for crimes such as treason, desertion in time of war, rebellion and insurrection, which have throughout history been deemed worthy of maximum punishment.

The more important Eighth Amendment question posed by penal expatriation is not whether it is excessive in amount when imposed for a particular crime, but whether it is a type of punishment which accomplishes deprivations so severe, of values so fundamental, as to be an unjustifiable punishment for any crime. ${ }^{86}$

Describing the deprivation of all nationality rights as "severe," concluded that expatriation is an unjustifiable punishment and should be barred by

${ }^{82}$ See Trop v. Dulles, 239 F.2d 527, 530 (2d Cir. 1956) (Clark, C.J., dissenting) (citing Comment, The Expatriation Act of 1954, 64 YALE L.J. 1164, 1189-99 (1955) and stating "I agree with the author's documented conclusions therein that punitive expatriation of persons with no other nationality constitutes cruel and unusual punishment and is invalid as such. Since I doubt if I can add to the persuasive arguments there made, I shall merely incorporate by reference."), rev'd, Trop v. Dulles, 356 U.S. 86 (1958).

${ }^{83}$ See generally Comment, supra note 82, at 1189-94.

${ }^{84}$ The author also observed that "[a]n 'unusual' punishment is defined as one that was unknown at common law or has become obsolete in modern times." Id. at 1187-88 (citing, inter alia, Weems v. U.S., 217 U.S. 349, 378 (1910) and In re Kemmler, 136 U.S. 436, 443, 447 (1890)).

${ }^{85}$ Comment, supra note 82, at 1188 (citing, inter alia, Weems v. U.S., 217 U.S. 349 (1910) and O’Neil v. Vt., 144 U.S. 323, 340 (1892) (Field, J., dissenting)).

${ }^{86} I d$. at 1194 (emphases added).

${ }^{87}$ Id. at 1189 . One could argue that the author distinguished between excessiveness in amount on one hand and whether the mode of punishment was cruel and unusual on the other. But closer analysis of his language shows that he identified "deprivations so severe ... as to be unjustifiable for any crime," which is language of absolute excessiveness. 
the Eighth Amendment. ${ }^{88}$ Under the author's reasoning, the punishment should be barred as violating the secondary type of absolute proportionality. In fact, the author explicitly recognized an "absolute limitation on the power to punish" when punishments, such as this one, are simply too severe. ${ }^{89}$ The Trop chief judge and plurality's wholesale adoption of the article's analysis, along with the Trop plurality's own characterizations of denationalization as severe, all demonstrate the core importance of some form of absolute proportionality. They also all demonstrate the importance of the Court's own judgment in determining the severity of punishment. Said another way, the Court's own proportionality analysis, whether it be of the primary or secondary absolute variety, is, at this time, firmly embedded in the Eighth Amendment assessment of what constitutes cruel and unusual punishment.

That is not to say, however, that more objective determinations had no role in the analysis of cruelty or unusualness. After its absolute proportionality assessment, and as the Court had done in some previous cases, the Trop plurality seemed to conduct a comparative proportionality analysis, referring to other nations' practices $^{90}$ and finding that " $[t]$ he civilized nations of the world are in virtual unanimity that statelessness is not to be imposed as punishment for crime." ${ }^{\text {"91 }}$ It did not clearly indicate where comparative analysis fit into the Eighth Amendment determination, whether, indeed, as a type of proportionality or as a measure of unusualness. ${ }^{22}$ In any event, it was a small part of the plurality's Eighth

${ }^{88} I d$. at 1194.

${ }^{89}$ See id. at 1188-89 (emphasis added).

${ }^{90}$ See Trop v. U.S., 356 U.S. 86, 102-03 (1958).

${ }^{91} \mathrm{Id}$. at 102.

${ }^{92}$ One could argue that the plurality's analysis in this case was not based on "unusualness" at all. In a footnote, it discussed whether the word "unusual" had any separate meaning in the Amendment, and if it did it must "signify something different from that which is generally done." Id. at 100 n.32. It then opined that denationalization met that test. But that the plurality did not tie this discussion about the meaning of "unusual" with the evidence of other nations' practices in the text of the opinion, and only tossed it off in a footnote, seems to reveal its view of the relative lack of importance of this measure to the Eighth Amendment determination.

Similarly, one portion of the Yale Law Journal comment relied on by Chief Judge Clark to find an Eighth Amendment violation discussed "the fact that the [punishment contained in the] Act conflicts with clearly formulated policies of the world community." Comment, supra note 82, at 1195 . But the author did not include this discussion of other nations' practices in his Eighth Amendment analysis, which occurred on pages 1187 to 1194 ; he included it when analyzing whether the punishment violated international law. See id. at 1195-99. 


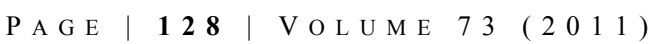

Amendment assessment in this case. ${ }^{93}$

In Trop, it is clear that the Court was relying on its own judgment to assess the excessive or disproportionate nature of the punishment, and that judgment seemed only to be buttressed by the evidence of other nations' practices. For this reason, the plurality appeared sensitive to a potential charge that its Eighth Amendment cruel and unusual punishment determination was based on justices' personal preferences and therefore outside of its province, ${ }^{94}$ pointedly concluding its opinion with a discourse on the obligation of the judiciary to judge legislative enactments by constitutional safeguards, "bearing in mind both the broad scope of legislative discretion and the ultimate responsibility of constitutional adjudication." ${ }^{95}$ They seemed defensive in acknowledging that theirs was a task to be undertaken cautiously. ${ }^{96}$ The Trop plurality's defense of its opinion anticipates criticisms about justices' personal preferences that endure in the late 20th- and early 21st-century Eighth Amendment adjudications.

As a matter of doctrine, though, what does the plurality's application of proportionality principles show us about the place of the evolving standards of decency in Eighth Amendment analysis? Recall that the Trop plurality saw the overarching "dignity of man" concept as primarily defined by civilized standards; recall also that the plurality capped its doctrinal discussion off with a reference to the evolving standards of decency and its role of informing the meaning of the Amendment. ${ }^{97}$ The preceding detailed examination of the plurality's application of these principles reveals that "the evolving standards of decency" concept itself incorporates ideas of absolute proportionality and also somewhat, but not explicitly, of unusualness or comparative proportionality. Absolute proportionality, or absolute excessiveness, is assessed by the Court, whereas unusualness or comparative proportionality could be thought of as a purely factual

\footnotetext{
${ }^{93}$ The plurality seemed less interested in this idea of "unusualness" than in ideas about proportionality and civilized standards. In a footnote, it referenced older cases in support of its opinion that "the Court simply examines the particular punishment involved in light of the basic prohibition against inhuman treatment, without regard to the subtleties of meaning that might be latent in the word "unusual." Trop, 356 U.S. at 100 n.32. Still less did it confine itself to (or even mention) some sort of "objective indicators" to determine whether the punishment transgressed the Amendment.

${ }^{94} \mathrm{Id}$. at 103 (insisting that "this task requires the exercise of judgment, not the reliance upon personal preferences").

${ }^{95}$ Id. at 104.

${ }^{96}$ See id. at $103-04$

${ }^{97}$ See supra notes $70-74$ and accompanying text.
} 
determination - but both may inform the content of the evolving standards of decency, which, in turn, give substance to civilized standards, which then capture the essence of the dignity of man.

In the next relevant case, the approach was not much different from that in Trop. In Robinson v. California, the Court applied the Eighth Amendment to a state punishment of imprisonment for at least ninety days for the crime of addiction to narcotics. ${ }^{98}$ In reaching its conclusion that a punishment for the status of addiction is cruel and unusual, the Court surmised that no state would punish mental illness or any other illness or disease as a crime..$^{99}$ That statement might suggest that the Court was objectively evaluating other states' practices, or employing comparative excessiveness analysis, in making its cruel and unusual punishment decision, but a closer look reveals that, in fact, it looked elsewhere: "in the light of contemporary human knowledge, a law which made a criminal offense of such a disease would doubtless be universally thought to be an infliction of cruel and unusual punishment ...."100 Primarily, then, the Court conducted an absolute excessiveness analysis, exhibiting its own view of the excessive nature of any penalty in the circumstances and based on the contemporary human knowledge in its possession. ${ }^{101}$ One might view its analysis as a sort of reverse absolute proportionality, in that it did not (and could not) view ninety days' imprisonment itself as excessive punishment for any crime; rather, the "crime" of addiction was something that simply could not be punished at all: "[t]o be sure, imprisonment for ninety days is not, in the abstract, a punishment which is either cruel or unusual. But the question cannot be considered in the abstract. Even one day in prison would be a cruel and unusual punishment for the 'crime' of having a common cold." 102 The Court's approach could be considered a form of primary absolute

${ }^{98}$ Robinson v. California, 370 U.S. 660, 660 \& n.1 (1962). For a discussion of Robinson, see Note, The Cruel and Unusual Punishment Clause and the Substantive Criminal Law, 79 HARV. L. REV. 635, 64550 (1966).

${ }^{99}$ Robinson v. California, 370 U.S. at 666.

${ }^{100} I d$. (emphasis added).

${ }^{101}$ The plurality's opinion in Gregg v. Georgia supports this reading because it cited Robinson as an example of when "legislative judgments alone cannot be determinative of Eighth Amendment standards since that Amendment was intended to safeguard individuals from the abuse of legislative power." 428 U.S. 153, 174 n.19 (1976) (stating further that Robinson "illustrates the proposition that penal laws enacted by state legislatures may violate the Eighth Amendment because 'in the light of contemporary human knowledge' they 'would doubtless be universally thought to be an infliction of cruel and unusual punishment"').

${ }^{102}$ Robinson, 370 U.S. at 667. 
U N I V E R S I T Y OF P I T T S B U R G H L A W R E V I E W

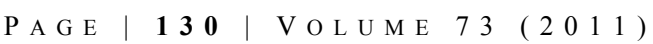

proportionality analysis: the severity of the offense or the culpability of the offender was so low, nonexistent in fact, that it could not be measured at all to justify any amount of punishment. Any punishment in this context would be excessive in relation to the "offense." Relying on nothing but its own judgment and knowledge about the severity of the offense and blameworthiness of the offender, and using no terms except the Eighth Amendment phrasing, the Court found a ninety-day prison term cruel and unusual punishment. The Court's tradition of evaluating punishments for excessiveness on its own continued in Robinson.

In employing concepts of absolute proportionality and also, to some degree, of comparative proportionality or unusualness, as aspects of the basic principles underlying the Eighth Amendment, the construct employed by the Trop v. Dulles plurality and the Robinson Court is nothing new or radical; it follows a long line of cases dating back to Reconstruction. A unifying thread can be seen over a hundredyear period in the Court's jurisprudence. Depending on the challenge, the Court would analyze punishments for excessiveness using its own measurement, and, if relevant, determine whether the type of punishment was uncommon or nontraditional using other states' or jurisdictions' practices as a comparative yardstick. But the driving consideration and focus has been absolute excessiveness, the Court's view of what was simply too much punishment. Absent from precedent has been an insistence on evaluating punishments by some objective, factually quantifiable measure. A three-judge plurality would alter this basic construct in the landmark case of Gregg v. Georgia. ${ }^{103}$

\section{GREGG V. GEORGIA AND BEYOND}

\section{A. A Plurality Reconstructs (or Misconstructs?) Eighth Amendment Doctrine}

Since 1976, when the Supreme Court reinstated capital punishment in Gregg v. Georgia ${ }^{104}$ after having struck it down in Furman v. Georgia, ${ }^{105}$ the Court's Eighth Amendment approach appears to have been basically stable. And although Gregg contains enough of the particulars of what had come before that it did not appear to be a clear shift from the Court's previous approach to these questions, a closer look shows that the Gregg approach did differ, and in some significant respects, from the century of pronouncements that had preceded it. The current

\footnotetext{
${ }^{103}$ Gregg v. Georgia, 428 U.S. 153 (1976) (plurality opinion).

${ }^{104} I d$.

${ }^{105}$ Furman v. Georgia, 408 U.S. 238 (1972).
} 
Eighth Amendment construct flows from the plurality opinion ${ }^{106}$ in Gregg, which first identified familiar, basic concepts. It noted the history of the clause and surveyed prior decisions, observing that "the Amendment has been interpreted in a flexible and dynamic manner" 107 and "'may acquire meaning as public opinion becomes enlightened by a humane justice." ${ }^{\prime 108}$ Further, the plurality acknowledged a "focus" on proportion, ${ }^{109}$ recognizing from Weems $v$. United States that it is a "precept of justice that punishment for crime should be graduated and proportioned to offense." 110 The Gregg plurality also referenced ideas about proportionality found in Trop v. Dulles. ${ }^{111}$ It then noted that there were "substantive limits imposed by the Eighth Amendment on what can be made criminal and punished." 112

With those observations about flexibility, proportionality, and substantive restrictions, the plurality set out what it viewed as the governing principles and, in the process, ultimately installed state legislatures' own judgments as central aspects of the constitutional test. ${ }^{113}$ First, "the Eighth Amendment has not been regarded as a static concept" but " "must draw its meaning from the evolving standards of decency that mark the progress of a maturing society.' Thus, an assessment of contemporary values" is necessary and "requires ... that we look to objective indicia that reflect the public attitude toward a given sanction." 114 The primary "objective" indicia of contemporary standards are legislative judgments, evidenced by state statutes ${ }^{115}$ and jury sentencing, "a significant and reliable objective index of contemporary values because [the jury] is so directly involved." ${ }^{116}$ As for

${ }^{106}$ The Gregg plurality consisted of Justices Stewart, Powell, and Stevens. 428 U.S. at 158.

${ }^{107} \mathrm{Id}$. at 171 .

${ }^{108} I d$. (quoting Weems v. United States, 217 U.S. 349, 378 (1910)).

${ }^{109} \mathrm{Id}$.

${ }^{110} I d$. at 172 (quoting Weems, 217 U.S. at 366-67).

${ }^{111} I d$. Although the plurality correctly noted that Trop acknowledged the concept of proportionality, it incorrectly stated that "the concept of proportionality was not the basis of the holding ...." Id. A close reading, as demonstrated in Part II.B of this article, reveals that proportionality most certainly was the basis of the holding in Trop. See supra notes 75-89 and accompanying text.

${ }^{112}$ Id. at 172 . The Gregg plurality also pointed to a trio of justices in concurring Furman opinions who "found the Eighth Amendment applicable to procedures employed to select convicted defendants for the sentence of death." Id. (emphasis added). That line of doctrine is beyond the scope of this article.

${ }^{113} I d$. at 175 .

${ }^{114} I d$. at 172-73 (quoting Trop v. Dulles, 356 U.S. 86, 101 (1958)).

${ }^{115}$ Id. at $175,179-81$.

${ }^{116} I d$. at 181 . 
PAGE

legislative enactments, the plurality expounded that they weigh heavily in the determination of contemporary standards because "in a democratic society legislatures, not courts, are constituted to respond to the will and consequently the moral values of the people." 117 Further, because the constitutional test is entwined with contemporary standards, "a heavy burden rests on those who would attack the judgment of the representatives of the people." "118 From the start, then, the Gregg plurality, more strongly than ever before, emphasized legislatures' own role in determining the constitutionality of their enactments under the Eighth Amendment. Previous opinions had recognized the presumption of statutory validity and the Court's deference to the states in criminal matters, ${ }^{119}$ but it seems a jump to move from deference and caution to permitting legislatures to set a substantial portion of the constitutional test. ${ }^{120}$ The three-justice plurality fashioned this "objective indicia" test out of whole cloth; prior opinions had referenced the importance of the evolving standards of decency, but nowhere in those opinions was there explicit reliance on other states' practices as a crucial measure of cruel and unusual punishment, to say nothing of requiring that the Court count legislative noses and jury decisions to determine standards of decency. ${ }^{121}$ The specific requirement to

${ }^{117} I d$. at 175 (emphasis added) (quoting Furman v. Georgia, 408 U.S. 238, 383 (1972) (Burger, C.J., dissenting)).

${ }^{118} I d$.

${ }^{119}$ See, e.g., Weems v. United States, 217 U.S. 349, 378-79 (1910).

${ }^{120}$ One commentator has argued that such "explicitly majoritarian state nose-counting" is common outside the Eighth Amendment context. See Corinna Barrett Lain, The Unexceptionalism of "Evolving Standards," 57 UCLA L. REV. 365 (2009).

${ }^{121}$ I have previously argued that the "objective" indicators cannot be considered truly objective (hence my use of quotation marks), because the constitutional construct itself influences some of the variables and because various justices have manipulated the data to achieve results they seemed to desire. Susan Raeker-Jordan, A Pro-Death, Self-Fulfilling Constitutional Construct: The Supreme Court's Evolving Standard of Decency for the Death Penalty, 23 HASTINGS ConST. L.Q. 455, 513-49 (1996) [hereinafter A Self-Fulfilling Construct]; see also Corinna Barrett Lain, Lessons Learned from the Evolution of “Evolving Standards," 4 CHARLESTON L. REV. 661, 674 (2010) [hereinafter Lessons Learned]. Another commentator finds the objective indicators "remarkably opaque and resistant to authoritative moral interpretation." Stinneford, supra note 75, at 1753. Still another has advanced various reasons why, in her view, it is illogical to use state legislation as evidence of the evolving standard of decency. See Tonja Jacobi, The Subtle Unraveling of Federalism: The Illogic of Using State Legislation as Evidence of an Evolving National Consensus, 84 N.C. L. REV. 1089 (2006). Two other commentators have noted that "the fact that numerous jurisdictions have the death penalty on the books appears to be less dispositive of the death penalty's consistency with prevailing societal norms," because moratoria, fewer death penalties and executions, new limits on the applicability of the penalty, and other developments all tend to show movement away from the penalty. Carol S. Steiker \& Jordan M. Steiker, Atkins v. Virginia: Lessons From Substance and Procedure in the Constitutional Regulation of Capital Punishment, 57 DePAUL L. REV. 721, 735-36 (2008). In their view, such developments may show an 
count state statutes came out of the blue and significantly changed Eighth Amendment doctrine and the Court's approach. ${ }^{122}$

A further observation is that the plurality, in this way, severed the evolving standard of decency from the "dignity of man" principle, which is essentially the embodiment of the values underlying the Cruel and Unusual Punishments Clause. The three-justice plurality stated that punishments are not only governed by what is currently acceptable to society but "[a] penalty also must accord with 'the dignity of man,' which is the 'basic concept underlying the Eighth Amendment.' This means, at least, that the punishment not be "excessive." "123 The plurality said that this idea of human dignity lies at the "core" of the Amendment. ${ }^{124}$ In recognizing that the "dignity of man" principle underlies the Amendment, the plurality was relying on first principles, on the principles relied on by the Court for over a century. But by separating the dignity of man concept from the evolving standards of decency analysis, and using evidence of popular will to assess the evolving standard, the plurality perhaps inadvertently did two things: First, it weakened the protections of the Amendment in a fundamental way. ${ }^{125}$ Rather than the Court being the final arbiter of what the Eighth Amendment means, it had now turned a good portion of that function over to the will of the masses, which the Amendment itself was meant to constrain. ${ }^{126}$ No longer was evidence of other states' practices

evolving standard of decency away from the penalty even without widespread legislative abolition. See id. at 735 .

${ }^{122}$ Cf. Lessons Learned, supra note 121, at 668-72.

${ }^{123}$ Gregg, 428 U.S. at 173 (citations omitted) (quoting Trop, 356 U.S. 86, 100 (1958)). Although the plurality quoted Trop $v$. Dulles when identifying what it treated as a second principle, the Trop Court did not treat the "dignity of man" concept separately from the "evolving standards of decency" idea. Instead, the evolving standard was all part of the "dignity of man" excessiveness measurement that the Court conducted, not a freestanding test of its own.

${ }^{124} \mathrm{Id}$. at 182 . It would seem to be an unassailable proposition that a fundamental reason for the inclusion of a provision forbidding cruel and unusual punishments is that we believe human beings possess some basic worth as human beings, and respect for that worth imposes some limits on how we punish fellow human beings. Otherwise, there would be no purpose for inclusion of such a clause.

${ }^{125}$ See also Stinneford, supra note 75, at 1754 ("Because the evolving standards of decency test ties the meaning of the Cruel and Unusual Punishments Clause to public opinion, the Eighth Amendment provides little protection when public opinion becomes enflamed [sic] and more prone to cruelty.")

${ }^{126}$ According to the plurality, however, it was retaining its role: "Although legislative measures adopted by the people's chosen representatives provide one important means of ascertaining contemporary values, it is evident that legislative judgments alone cannot be determinative of Eighth Amendment standards since that Amendment was intended to safeguard individuals from the abuse of legislative power." Gregg, 428 U.S. at 174 n.19. This article does not contend that legislative judgments alone determine the standard; rather, it argues that by changing the approach as it did in Gregg, the plurality 
to serve just as some evidence of unusualness; now it would constitute a primary measure of constitutionality. But it was the majority population's excesses that the Eighth Amendment was supposed to restrict, and it was the Court's job to apply that restriction by providing an impartial judgment on excessiveness or lack of proportionality, just as it did for over a hundred years. The change in construct weakened that bulwark against popular excesses. Second, by treating the evolving standard of decency as a measure apart from the "dignity of man" concept, the plurality implicitly and strangely acknowledged that what was popular among legislatures and juries may have nothing to do with protecting and preserving the dignity of man. ${ }^{127}$ When thought about that way, the decoupling of the two concepts makes some bizarre sense; if one's view is that popular will should determine the meaning of "cruel and unusual punishment," it does not necessarily follow that popular will would comport with the "dignity of man" idea. History is full of popular demands for justice in the form of certain grotesque punishments that we would consider barbaric and violative of man's dignity. But recognition that the concepts are not necessarily related should itself condemn the "objective" indicators of the evolving standards of decency, since the Amendment surely was intended to protect against the excesses of state legislatures, even if clamored for by the public. The three-justice plurality believed that the "objective" standards were necessary to balance the presumed validity of a state criminal legislative enactment against the real constraint that a constitutional provision places on the states, ${ }^{128}$ but it went too far.

To review up to this point, then, the plurality reconstructed or arguably misconstructed the Eighth Amendment analysis on a macro level by separating the evolving standards of decency from the "dignity of man" excessiveness/ proportionality analysis. ${ }^{129}$ It also reconstituted the evolving standards of decency

\footnotetext{
enabled the ascendance of legislative judgments as a major part of the calculus, thereby ultimately weakening Eighth Amendment protections.

${ }^{127}$ I have previously made a similar observation from another perspective. See A Self-Fulfilling Construct, supra note 121, at 465 n.31.

${ }^{128}$ See Gregg, 428 U.S. at 174-76.

${ }^{129}$ Estelle v. Gamble, 429 U.S. 97 (1976), decided four months after Gregg and involving the alleged failure to adequately treat the medical needs of a prisoner, treated the two ideas distinctly as well, separating the evolving standard of decency from a proportionality analysis. See id. at 98-101, 102, 103 n.7 (stating that "we have held repugnant to the Eighth Amendment punishments which are incompatible with "the evolving standards of decency that mark the progress of a maturing society," and that "[t]he Amendment also proscribes punishments grossly disproportionate to the severity of the crime ....") (citations omitted). But the Estelle Court characterized the evolving standard, rather than the proportionality guarantee, as a measure of the humanity and dignity concerns of the Amendment.
} 
by requiring reliance on so-called objective indicators. ${ }^{130}$ But the plurality also made changes on a more micro level to the way it approached the other half of the analysis: the excessiveness, or proportionality inquiry.

First and most importantly, the plurality seemed to attempt to give some contours to the absolute excessiveness analysis that would constrain the Court in using its own judgment by requiring it to objectivize as much as possible the excessiveness assessment while at the same time not relinquishing the meaning of the Amendment to the masses. This development should be viewed as a positive one. Under the Gregg plurality's formulation, the excessiveness principle, or respect for basic human dignity, now required that the punishment "not involve the unnecessary and wanton infliction of pain." 131 The plurality refined this idea further to require some penological justification for the punishment, since without some valid purpose, punishment would be "the gratuitous infliction of suffering" 132 and therefore unnecessary and excessive. In the death penalty context, then, that requirement meant that punishment must serve the purposes of retribution or deterrence ${ }^{133}$ if it does not serve those goals, it is unnecessary, excessive, violative of the dignity of man, and therefore cruel and unusual punishment.

See id. at 102 ("The Amendment embodies 'broad and idealistic concepts of dignity, civilized standards, humanity, and decency..., against which we must evaluate penal measures. Thus we have held repugnant to the Eighth Amendment punishments which are incompatible with 'the evolving standards of decency that mark the progress of a maturing society."') (citation omitted). In fact, the proportionality aspect of the Amendment was only noted in a footnote. See id. at 103 n.7. Although the Estelle Court did not stress the use of objective indicators, it did use evidence of legislative enactments to determine the evolving standard of decency: the treatment given the prisoner there was "inconsistent with contemporary standards of decency as manifested in modern legislation ...." Id. at 103. Again confusing the doctrine, the Court in another prison-conditions case also removed the proportionality guarantee from the dignity concerns underlying the Amendment. See Hutto v. Finney, 437 U.S. 678, 685 (1978) ("The Eighth Amendment's ban on inflicting cruel and unusual punishments ... prohibits penalties that are grossly disproportionate to the offense as well as those that transgress today's broad and idealistic concepts of dignity, civilized standards, humanity, and decency.") (internal quotation marks omitted). Because these are conditions of confinement cases, they had little reason to explore the role of proportionality and, for that reason, are not as useful for this article.

${ }^{130}$ Gregg, 428 U.S. at 173.

${ }^{131} I d$.

${ }^{132}$ Id. at 183 . But see Lee, supra note 6, at 683 (arguing that "a reading of the proportionality limitation in the Eighth Amendment that boils down to the position that any punishment is constitutionally permissible as long as it satisfies an accepted purpose is at odds with the general logic of the Eighth Amendment," because "[t]he purpose of the Eighth Amendment ... is to place constraints on the ways in which we pursue these [purposes]").

${ }^{133}$ Gregg, 428 U.S. at 183-84. Retribution is achieved because "capital punishment is an expression of society's moral outrage at particularly offensive conduct." Id. at 183. 
Second, and at least in this case of a challenge to the death penalty qua penalty, the Gregg plurality also retained a more general proportionality assessment, identifying it as the second aspect of excessiveness: "[T]he punishment must not be grossly out of proportion to the severity of the crime."134 The plurality had little difficulty determining that when murder is involved, execution is not invariably disproportionate to the crime. ${ }^{135}$ But it did not give any more guidance about measuring proportionality in future cases not falling under the general rule or when other circumstances, such as the status or blameworthiness of the defendant or the type of crime, might change the proportionality calculus. In fact, it should be viewed as being substantially the same as the retribution analysis, since that analysis will typically evaluate whether the punishment fits the crime and defendant. In any event, all of the excessiveness determination, by the Gregg plurality's terms, was for the Court: "[O]ur cases also make clear that public perceptions of standards of decency ... are not conclusive"136 but that "[t] he Court also must ask whether [the punishment] comports with the basic concept of human dignity at the core of the Amendment." 137

The plurality seemed to angst over this aspect of the Court's constitutional role, sounding a familiar refrain ${ }^{138}$ about the "limited role" that courts should play in assessing the constitutionality of state legislative judgments in our federal system, particularly where punishments and policies about punishments are concerned: "[W]e may not act as judges as we might as legislators." 139 As previously noted, in assessing the constitutionality of a punishment, the Court presumes its validity. ${ }^{140}$ But then the Court swung right back to its own authority: "This does not mean that judges have no role to play, for the Eighth Amendment is

${ }^{134}$ Id. at 173.

${ }^{135}$ Id. at 187.

${ }^{136} I d$. at 173 (emphasis added).

${ }^{137}$ Id. at 182 (emphasis added). In discussing whether the death penalty furthered goals of punishment, the plurality had deferred to the Georgia legislature's conclusion that deterrence and retribution were furthered. But the justices were clear that they accorded deference because of the lack of more convincing evidence against Georgia's position and because of considerations of federalism. Id. at 18687.

${ }^{138}$ See, e.g., Trop v. Dulles, 356 U.S. 86, 103-04 (1958); Weems v. United States, 217 U.S. 349, 379 (1910).

${ }^{139}$ Gregg, 428 U.S. at $174-76$.

${ }^{140} I d$. at 175 . 
a restraint upon the exercise of legislative power."141 This balancing act has been the source of much tension in the Court's Eighth Amendment jurisprudence, which has only been exacerbated by the insistence that state punishment statutes play such a large role in the Eighth Amendment test.

The Gregg plurality improperly put its thumb on the scale toward majoritarian control of the Eighth Amendment and away from protection of individual rights when it so clearly required "objective" indicators of society's decency standards as part of the Eighth Amendment analysis. And despite the plurality's contention that public perceptions of decency standards were not conclusive, separating and requiring the two inquiries permitted the later elevation of those "objective" aspects of the test. ${ }^{142}$

In fact, the elevation of the objective indicators occurred rather quickly, in the Court's next term, in the case of Coker v. Georgia. ${ }^{143}$ There, the plurality opinion stated, "these Eighth Amendment judgments should not be, or appear to be, merely the subjective views of individual justices; judgment should be informed by objective factors to the maximum possible extent." "144 True, it also said that "[t]hese recent events evidencing the attitude of state legislatures and sentencing juries do not wholly determine this controversy, for the Constitution contemplates that in the end our own judgment will be brought to bear on the question of the acceptability of the death penalty under the Eighth Amendment." ${ }^{, 145}$ But that statement of

\footnotetext{
${ }^{141}$ Id. at 174 . This idea can be found in Trop v. Dulles as well: "We must apply [constitutional] limits as the Constitution prescribes them, bearing in mind both the broad scope of legislative discretion and the ultimate responsibility of constitutional adjudication.” 356 U.S. 86, 104 (1958) (plurality opinion); see also supra notes $94-96$ and accompanying text.

${ }^{142}$ In fact, some justices have since fully renounced the balancing act and adopted an Eighth Amendment test that moves to one end of the scale, insisting that the objective indicators constitute the only measure of constitutionality. See, e.g., Stanford v. Kentucky, 492 U.S. 361, 377-79 (1989) (plurality opinion), abrogated by Roper v. Simmons, 543 U.S. 551 (2005). Other justices continue to include the evidence of legislative judgment but ultimately exercise their own judgment about excessiveness. See, e.g., Atkins v. Virginia, 536 U.S. 304, 311-13 (2002). Outside the Court, there has been criticism of the Court's use of its own judgment. For just one example, see Bradford R. Clark, Constitutional Structure, Judicial Discretion, and the Eighth Amendment, 81 Notre Dame L. Rev. 1149 (2006).

${ }^{143} 433$ U.S. 584, 592 (1977) (plurality opinion).

${ }^{144} \mathrm{Id}$. at 592 (emphasis added). Another reason for looking to these indicators, identified by Justice Stevens writing for a plurality in Thompson v. Oklahoma, 487 U.S. 815, 823 n.7 (1988), stems from the word "unusual" in the Eighth Amendment; if legislatures provide for the punishment and juries impose it, it is not unusual.

${ }^{145}$ Coker, 433 U.S. at 597 (emphasis added).
} 
maximum reliance on objective factors, made in the year just following the plurality opinion of Gregg v. Georgia, further shifted the focus away from the Court's assessment of excessiveness and toward more majoritarian control of constitutional interpretation. The "maximum reliance" statement has been quoted and relied on in cases since Coker. ${ }^{146}$ Perhaps it is no coincidence that heavier reliance on objective factors such as legislative enactments occurred in a case in which the Court did not once mention the dignity of man underlying the Amendment. The phrase dropped out of some of the cases following, ${ }^{147}$ as well, until it was resurrected in 2002 in Atkins v. Virginia and in 2005 in Roper v. Simmons. ${ }^{148}$ The maximum influence accorded the "objective" indicators would dilute the primacy of the "dignity of man" principle and ultimately doctrinally weaken the Eighth Amendment protections. In the meantime, however, the Court would take up the Eighth Amendment proportionality issue in some notable nondeath penalty cases.

\section{B. Tensions Emerge in Non-Death Penalty Cases}

After Gregg, the Court in non-death penalty cases continued to thrash through the proportionality aspect of the Eighth Amendment. The question whether the Eighth Amendment contained a proportionality guarantee at all seemed settled in Solem v. Helm. ${ }^{149}$ Addressing whether the Eighth Amendment prohibits a sentence

${ }^{146}$ See, e.g., Enmund v. Florida, 458 U.S. 782, 788 (1982) ("In reaching [the conclusion that the death penalty was excessive in Coker v. Georgia], it was stressed that our judgment 'should be informed by objective factors to the maximum possible extent."') (emphasis added) (quoting Coker, 433 U.S. at 592); see also Harmelin v. Michigan, 501 U.S. 957, 1000 (1991) (Kennedy, J., concurring in part and concurring in the judgment); id. at 1015 (White, J. dissenting); Stanford v. Kentucky, 492 U.S. 361, 369 (1989). Although the Court did not quote Coker in McCleskey v. Kemp, it recognized that "[i]n assessing contemporary values, we have eschewed subjective judgment, and instead have sought to ascertain 'objective indicia' ...”" 481 U.S. 279, 300 (1987). Justice O'Connor also stated in Penry v. Lynaugh, 492 U.S. 302, 335 (1989) that "[we] [r]ely[] largely on objective evidence such as the judgments of legislatures and juries ...."

${ }^{147}$ See Stanford v. Kentucky, 492 U.S. 361 (1989) (four-justice plurality opinion of Justice Scalia); Penry v. Lynaugh, 492 U.S. 302 (1989); Thompson v. Oklahoma, 487 U.S. 815 (1988) (four-justice plurality opinion of Justice Stevens); Enmund v. Florida, 458 U.S. 782 (1982). But the principle was mentioned in Stanford v. Kentucky, 492 U.S. 361, 392 (1989) (four-justice dissenting opinion of Justice Brennan); McCleskey v. Kemp, 481 U.S. 279, 300 (1987); and Ford v. Wainwright, 477 U.S. 399, 406 (1986).

${ }^{148}$ See Atkins v. Virginia, 536 U.S. 304, 311 (2002); Roper, 543 U.S. at 560 (2005) (noting the "dignity of all persons"). In those cases, a majority of the Court struck down death sentences imposed on people with mental retardation and juveniles, respectively.

${ }^{149} 463$ U.S. 277 (1983). 
of life without parole for the commission of a seventh nonviolent felony, ${ }^{150}$ a majority of the Court stated, "The final [Eighth Amendment] clause prohibits not only barbaric punishments, but also sentences that are disproportionate to the crime committed." ${ }^{151}$ The Justices in the majority agreed that the Eighth Amendment contained a proportionality guarantee not only in death penalty cases but also in cases involving fines and prison sentences. ${ }^{152}$

For purposes of this article, however, perhaps the most interesting portion of the opinion is the discussion about measuring proportionality. The Court stated that "a court's proportionality analysis under the Eighth Amendment should be guided by objective criteria, including (i) the gravity of the offense and the harshness of the penalty; (ii) the sentences imposed on other criminals in the same jurisdiction; and (iii) the sentences imposed for commission of the same crime in other jurisdictions." ${ }^{153}$ All three ways of measuring proportionality have been employed in the past, ${ }^{154}$ and in that regard Solem was consistent with pre-Gregg proportionality jurisprudence. But that very consistency, coming as it did after Gregg's reworking of the Eighth Amendment construct, muddled the doctrine.

To begin the muddling, the first "objective" Solem criterion was not included in the list of objective indicators by the Gregg plurality; only legislative enactments and jury decision-making were included as indicia of the evolving standards of decency $^{155}$ (effectively Solem's third objective criterion). In fact, just the opposite is true: a reading of the remainder of the Gregg opinion clearly shows that the plurality did not consider that first factor to be "objective" but instead considered it within its province to measure for itself the severity of the penalty against the seriousness of the offense. ${ }^{156}$ And as a practical matter, such measurement would

\footnotetext{
${ }^{150} I d$. at 279.

${ }^{151} I d$. at 284 .

${ }^{152}$ Id. at 288-89. There were mentions of the Eighth Amendment proportionality protection in other cases after Gregg and preceding Solem. For example, in Estelle v. Gamble, 429 U.S. 97,103 n.7 (1976), a conditions-of-confinement case decided four months after Gregg, the Court said "[t]he Amendment also proscribes punishments grossly disproportionate to the severity of the crime ...," but the statement was dicta because disproportionality was not an issue in the case. See id. The Court said the same in dicta in Ingraham v. Wright, 430 U.S. 651, 667 (1977). Much later, a majority would affirm the "clearly established" rule that "[a] gross proportionality principle is applicable to sentences for terms of years." Lockyer v. Andrade, 538 U.S. 63, 72 (2003); see also Graham v. Florida, 130 S. Ct. 2011, 2021 (2010).

${ }^{153}$ Solem v. Helm, 463 U.S. 277, 292 (1983).

${ }^{154}$ For examples, see $i d$. at $290-92$.

${ }^{155}$ See Gregg v. Georgia, 428 U.S. 153, 173, 179-82 (1976) (plurality opinion).

${ }^{156}$ See id. at 173-76, 187.
} 
necessarily have an element of subjectivity, as "severity," "harshness," "gravity," and "seriousness" are simply not objectively quantifiable assessments. ${ }^{157}$ But while the Solem Court's identification of this criterion as objective arguably confuses the doctrine, it has the salutary effect of equating the methods of measuring proportionality, thereby diminishing the Gregg plurality's elevation of its "objective" criteria and its consequent weakening of Eighth Amendment protections. In addition, by equating the three criteria as valid aspects of proportionality analysis, Solem was consistent with pre-Gregg understandings of proportionality in the Eighth Amendment, as previously chronicled in this article. From that perspective, then, it is Gregg and not Solem that is the problem case.

Further disordering occurred in Solem when, again in contrast to Gregg, the Court designated the last two Solem criteria as part of the proportionality analysis rather than as separate, distinct assessments of the evolving standard of decency. But again, including them under one proportionality umbrella restored the preGregg approach of treating the various measurements as equal components of excessiveness or proportionality analysis, so to the extent that the construct is different from that in Gregg, it is Gregg that departed from precedent, not Solem.

The doctrine became even more of a muddle eight years later in Harmelin $v$. Michigan. ${ }^{158}$ The case involved a disproportionality challenge to a mandatory sentence under Michigan law of life without parole for possession of 672 grams of cocaine. ${ }^{159}$ Five members of the Court eventually agreed that the sentence did not amount to cruel and unusual punishment. ${ }^{160}$ But the Court split many ways on Eighth Amendment proportionality doctrine, with separate opinions authored by Justice Scalia, joined by Chief Justice Rehnquist; ${ }^{161}$ Justice Kennedy, joined by Justices O'Connor and Souter; ${ }^{162}$ and Justice White, joined by Justices Blackmun

\footnotetext{
${ }^{157}$ For the Court's explanation of the objective nature of this analysis, see Solem, 463 U.S. at 292-94.

${ }^{158} 501$ U.S. 957 (1991).

${ }^{159}$ Id. at 961 .

${ }^{160}$ See id. at 961, 994-96 (stating that the Eighth Amendment does not prohibit mandatory sentences, such as the one at issue). Two justices, Scalia and Rehnquist, concluded simply that the Eighth Amendment contains no proportionality guarantee outside of the capital punishment context, so Michigan's sentence could not violate the Amendment on that basis. See id. at 965, 994. Three other justices, Kennedy, O'Connor, and Souter, found a proportionality principle in the Amendment but concluded that the sentence did not violate it. See id. at 996-97, 1008-09.

${ }^{161}$ See id. at 962-94.

${ }^{162}$ See id. at 996-1005 (Kennedy, J., concurring in part and concurring in the judgment).
} 
and Stevens. ${ }^{163}$ No clear proportionality rule emerged from Harmelin. For purposes of this article, most important is the opinion of Justice Kennedy, because he provided his view of the ways to evaluate Eighth Amendment proportionality, giving insight into the development of his thinking on the way to later death penalty opinions. ${ }^{164}$

Justice Kennedy opined that Eighth Amendment precedent established a narrow proportionality guarantee that "forbids only extreme sentences that are 'grossly disproportionate' to the crime." "165 This principle flowed from four other principles he found in Eighth Amendment precedent, including "the primacy of the legislature, the variety of legitimate penological schemes, the nature of our federal system, and the requirement that proportionality review be guided by objective factors ...."166 As for the last principle, Justice Kennedy echoed the recent refrain that the courts should be informed in their proportionality judgment by objective indicators "to the maximum possible extent."167

Justice Kennedy's approach to proportionality review employed the "objective" three-factor list in Solem but with a different emphasis. In his view, the first step was for the Court to assess the severity of the crime and the harshness of the penalty. Only if that review raised an inference of gross disproportionality would the Court go on to conduct intra-jurisdictional (examining other sentences for other crimes in the jurisdiction) and inter-jurisdictional (examining other jurisdictions' sentences for this crime) comparative analyses: "The proper role for comparative analysis of sentences ... is to validate an initial judgment that a

\footnotetext{
${ }^{163}$ See id. at 1009-21 (White, J., dissenting). Justice Marshall dissented separately but agreed with Justice White's proportionality discussion. Id. at 1027-28 (Marshall, J., dissenting).

${ }^{164}$ Justice Kennedy's opinion is also noteworthy because a plurality adopted his Harmelin approach in Ewing v. California, 538 U.S. 11, 23-24 (2003) (plurality opinion). The Ewing plurality added the gloss that the sentence would not be grossly disproportionate if the state has a "reasonable basis for believing" that its sentence would "advance the goals of [its] criminal justice system in any substantial way." Id. at 28 (quoting Solem v. Helm, 463 U.S. 277, 297 n.22 (1983)) (alteration in original). In Graham v. Florida, 130 S. Ct. 2011, 2021-22 (2010), a majority agreed with the characterization of Justice Kennedy's Harmelin opinion as the "controlling opinion."

${ }^{165}$ Harmelin, 501 U.S. at 1001 (Kennedy, J., concurring in part and concurring in the judgment).

${ }^{166} I d$. Although the first three are found in precedent, one can quarrel with the pedigree of the last principle and the emphasis placed upon it, because as shown above and below it is of recent vintage: the pluralities in the 1976 Gregg case and the 1977 Coker case stated it without any supporting authority. See Gregg v. Georgia, 428 U.S. 153, 173 (1976) (plurality opinion); Coker v. Georgia, 433 U.S. 584, 592 (1977) (plurality opinion).

${ }^{167}$ Harmelin, 501 U.S. at 1000 (internal quotations omitted).
} 
sentence is grossly disproportionate to a crime."168 Employing that approach, Justice Kennedy examined the harshness of the penalty, describing life without parole as the "second most severe penalty permitted by law." 169 Assessing the seriousness of the defendant's crime of possession of a large amount of cocaine, he concluded that "petitioner's crime threatened to cause grave harm to society," as borne out by studies showing "a direct nexus between illegal drugs and crimes of violence." sentence of life without parole could be seen as warranted by the punishment goals of deterrence and retribution. ${ }^{171}$

The notable aspects of Justice Kennedy's opinion in Harmelin are threefold. First, Justice Kennedy characterized the above assessment as "objective," even though it requires justices to use their own judgment about severity of crimes and harshness of penalties. Although there may be a small element of objectivity to those determinations (e.g., killing two people is worse than killing one person), certainly those judgments are more subjective than simply tallying the number of states that punish cocaine possession with a life-without-parole sentence.

The first observation leads to the second notable aspect of Justice Kennedy's opinion, which is that he emphasized the Court's subjective assessment; if that assessment did not show gross disproportionality, then the other two, more objective, factors were not relevant. ${ }^{172}$ If, however, the Court's analysis raised an inference of disproportionality, then the other comparative objective analyses could be used to validate the Court's judgment. In Harmelin, it appears as if Justice Kennedy placed the greatest emphasis on the Court's own judgment about proportionality and less reliance on more typical "objective" factors.

The third notable observation about Justice Kennedy's opinion here is its fidelity to 130 years of precedent. Since Pervear v. Commonwealth through Weems v. United States and Trop v. Dulles, the Court has examined a penalty for its

\footnotetext{
${ }^{168} I d$. at 1005 (emphasis added).

${ }^{169} \mathrm{Id}$. at 1001 .

${ }^{170} I d$. at $1002-03$.

${ }^{171} I d$. at 1003 .

${ }^{172}$ A commentator has argued that the Court's application of its threshold test leaves non-capital cases unpoliced and renders proportionality "virtually meaningless as a constitutional principle" in non-capital cases. Rachel E. Barkow, The Court of Life and Death: The Two Tracks of Constitutional Sentencing Law and the Case for Uniformity, 107 MICH. L. REV. 1145, 1156, 1160-61 (2009) (internal quotations omitted).
} 
harshness. Only after that analysis did it look, in some manner, to more objective determinations, such as other states' punishment practices. Although he summoned the recently created refrain about relying on objective factors to the maximum possible extent, he relied more on the Court's own judgment about proportionality. In different words but to the same effect, Justice Kennedy was faithful to the Court's historic Eighth Amendment approach and principles.

Although Justice Kennedy's opinion in Harmelin and the Court's opinion in Solem v. Helm, both non-capital cases, are in large measure consistent with preGregg Eighth Amendment precedent, somehow neither provided real clarity on the proper application of the Eighth Amendment's proportionality guarantee, ${ }^{173}$ even if only in non-capital cases. ${ }^{174}$ Justice Kennedy's Harmelin opinion provides a window into how he would approach proportionality analysis in capital cases, but there would be significant disagreement on the Court about the appropriate measurement of excessiveness - and application of the Eighth Amendment-in capital punishment.

\section{Post-Gregg Capital Cases}

In death penalty cases post-Gregg, all of the justices agreed that cruel and unusual punishment should at least be measured with the evolving standards of decency, determined by looking in large part to legislative enactments: what the states were doing was a measure of decency, and therefore, of cruelty and unusualness. The sticking point concerned proportionality more generally and whether the Court should, in addition, employ its own judgment in determining whether a punishment was simply too much, excessive in relation to the seriousness of the crime, and therefore cruel and unusual punishment. More justices than not believed in the Court employing its own judgment and then supporting that judgment with objective evidence of the evolving decency standard. ${ }^{175}$ Fewer, less than a majority, were stridently opposed to the Court using

\footnotetext{
${ }^{173}$ The Court itself has recognized the lack of clarity in its own decisions. See Lockyer v. Andrade, 538 U.S. 63, 72 (2003) (stating that "our precedents in this area have not been a model of clarity" and that "in determining whether a particular sentence for a term of years can violate the Eighth Amendment, we have not established a clear or consistent path for courts to follow").

${ }^{174}$ For fuller discussions of non-capital Eighth Amendment proportionality cases, see, for example, Barkow, supra note 172, at 1156-62; Donna H. Lee, Resuscitating Proportionality in Noncapital Criminal Sentencing, 40 ARIZ. ST. L.J. 527 (2008); Frase, supra note 6, at 576-88; Steven Grossman, Proportionality in Non-Capital Sentencing: The Supreme Court's Tortured Approach to Cruel and Unusual Punishment, 84 KY. L.J. 107 (1996).

175 See, e.g., Atkins v. Virginia, 536 U.S. 304, 305, 312-13 (2002) (Justices Stevens, O’Connor, Kennedy, Souter, Ginsburg, and Breyer joining an opinion applying the Court's own judgment to the Eighth Amendment proportionality determination). Justice Sotomayor, a 2009 appointment to the Court,
} 
its own judgment, accusing those who used the approach of deciding Eighth Amendment violations according to their personal predilections. ${ }^{176}$ These justices advocated stripping away the century-old proportionality analysis, in which justices measured the severity of the penalty against the seriousness of the crime, and replacing it almost solely with the evolving standards of decency as indicated by what states were doing. ${ }^{177}$ Their method would assess a punishment by what majorities preferred, which would not necessarily correspond with what respected the dignity of man at the heart of the Eighth Amendment.

This significant doctrinal disagreement resulted in fractured opinions and left the doctrine in disarray. A few examples will suffice to make the point. Thompson v. Oklahoma held that execution of juveniles ages fifteen and younger was cruel and unusual punishment, in large part because it was excessive for those in an age group known for its impulsiveness and immature judgment. ${ }^{178}$ Thompson was a split decision, with five justices using their own judgment about excessiveness, in addition to the objective evidence, ${ }^{179}$ and four not, the latter relying only on the objective indicators and historical practice. ${ }^{180}$ When the issue of juveniles came up again in Stanford $v$. Kentucky, this time regarding sixteen- and seventeen-year-olds, a different plurality decided that execution of members of this age group was not cruel and unusual punishment because not enough states prohibited their

see Members of the Supreme Court of the United States, SuPremECOURT.GOv, http://www .supremecourt.gov/about/members.aspx (last visited Sept. 9, 2011), has agreed that the Court must apply its own judgment on these questions. See Graham v. Florida, 130 S. Ct. 2011, 2016, 2022 (2010) (Justice Sotomayor joining the majority opinion of Justice Kennedy indicating the necessity of the Court employing its own judgment).

${ }^{176}$ See, e.g., Atkins v. Virginia, 536 U.S. 304, 337, 348 (2002) (Justice Scalia, in dissent, joined by Chief Justice Rehnquist and Justice Thomas, derided the majority's use of its own judgment as an "[arrogant] assumption of power [that] takes one's breath away" and that is simply an expression of the justices' own "feelings and intuition."); Roper v. Simmons, 543 U.S. 551, 607-08 (2005) (Justice Scalia, in dissent, joined by Chief Justice Rehnquist and Justice Thomas, characterized the majority's use of its own judgment as merely its "subjective views.").

${ }^{177}$ See, e.g., Stanford v. Kentucky, 492 U.S. 361, 364, 377-80 (1989) (plurality opinion of Justice Scalia joined by Chief Justice Rehnquist and Justices White and Kennedy) (disclaiming reliance on indicia of societal views other than legislative enactments and criticizing reliance on measures of proportionality), abrogated by Roper v. Simmons, 543 U.S. 551 (2005).

${ }^{178}$ Thompson v. Oklahoma, 487 U.S. 815, 833-38 (1988) (plurality opinion).

179 Justices Stevens, Brennan, Marshall, and Blackmun were joined on the general doctrinal point by Justice O'Connor. See id. at 818, 833 (plurality opinion); id. at 853-54 (O'Connor, J., concurring in the judgment).

${ }^{180}$ See id. at 873 (Scalia, J., dissenting, joined by Chief Justice Rehnquist and Justice White). 
executions. ${ }^{181}$ Four justices relied almost exclusively on that evidence. ${ }^{182}$ The other five justices insisted their own judgments about excessiveness played an important role in Eighth Amendment proportionality analysis. ${ }^{183}$ Similar results are on exhibit in Penry v. Lynaugh. ${ }^{184}$

What these cases demonstrate is not only a strong schism that left the law in a state of flux but also an upending of the traditional Eighth Amendment approach. Whereas the emphasis since 1866 had been on proportionality and the Court's own assessment of too much punishment, the emphasis post-Gregg was moving toward the opposite end of the spectrum. At least in Gregg, the plurality acknowledged a role for the Court's judgment about excessiveness, coupled with a measurement of state legislatures' approval of the punishment level. Now some justices strongly advocated dispensing with the Court's judgment and hanging the Eighth Amendment determination solely on the practices of a certain key number of state legislatures. Unmoored from any sense of what constitutes too much punishment, the cruelty and unusualness assessment would be the prerogative of state legislatures. If enough state legislatures imposed a punishment, it would not be cruel and unusual, no matter how excessive most justices thought it might be. The pendulum was swinging away from independent judicial interpretations of the Eighth Amendment, which would impose some constitutional constraint on legislative excesses, toward exclusively legislative discretion in punishment, which would weaken, if not eviscerate, the Eighth Amendment's protection of individuals against the tyranny of the majority. But the pendulum would not swing all the way; the Court would begin to reassert first principles.

\section{The Construct Is Rearranged}

One can discern a tentative nod to the earliest Eighth Amendment approach with Justice Stevens's opinion in Atkins v. Virginia, ${ }^{185}$ which only slightly shifted

181492 U.S. 361 at 370-73 (1989) (plurality opinion of Justice Scalia joined by Chief Justice Rehnquist and Justices White and Kennedy) (stating that enacted laws are "the primary and most reliable indication of consensus [of the standard of decency]").

${ }^{182}$ See id. at $377-80$.

${ }^{183}$ See id. at 382 (O’Connor, J., concurring in part and concurring in the judgment); id. at 383 (Brennan, J., dissenting, joined by Justices Marshall, Blackmun, and Stevens).

${ }^{184} 492$ U.S. 302 at 335-36 (1989) (opinion of O’Connor, J.); id. at 342-43 (Brennan, J., concurring in part and dissenting in part); $i d$. at 350 (Stevens, J., concurring in part and dissenting in part); $i d$. at 351 (Scalia, J., concurring in part and dissenting in part).

${ }^{185} 536$ U.S. 304 (2002). 
emphasis back to the "dignity of man" principle. ${ }^{186}$ The case challenged the death penalty for people with mental retardation.

Justice Stevens began by discussing excessiveness, indicating that punishments must be proportional. ${ }^{187} \mathrm{He}$ then linked the excessiveness or proportionality inquiry to the "dignity of man" principle and the evolving standard of decency, stating that excessiveness or proportionality is judged by current standards. ${ }^{188}$ Although to this point he clearly reverted to a Weems- and Trop-era construct, which employed the principles used by the Court for almost a century, he then said the following: "Proportionality review under those evolving standards should be informed by objective factors to the maximum possible extent," state legislative judgments being the most reliable of the objective factors. ${ }^{189}$ As noted previously, neither Weems nor the Trop plurality, nor any Court before them, imposed an objective requirement on the evolving standard of decency assessment, but each, in fact, conducted its own review of proportionality and excessiveness; the standard of decency was determined by the Court, under the concept of the dignity of man.

On introducing the excessiveness analysis, Justice Stevens's opinion recognized that "the objective evidence, while of great importance, did not "wholly determine' the controversy, 'for the Constitution contemplates that in the end our

\footnotetext{
${ }^{186}$ Although the plurality in Coker v. Georgia and the majority in Enmund v. Florida did not refer to the "dignity of man" principle, they followed the basic construct employed by the Atkins and Roper majorities, which relied on both the objective factors of the evolving standards of decency and the Court's own judgment about excessiveness to determine whether the punishment was cruel and unusual. See Coker v. Georgia, 433 U.S. 584, 597 (1977); Enmund v. Florida, 458 U.S. 782, $788-89$ (1982). The pluralities carrying the day in Stanford v. Kentucky, 492 U.S. 361, 377-80 (1989) (plurality opinion) and Penry v. Lynaugh, 492 U.S. 302, 330-31, 350-51 (1989), placed exclusive reliance on the objective indicators to determine proportionality and thus the cruel and unusual nature of the punishment.

${ }^{187}$ Atkins v. Virginia, 536 U.S. 304, 311 (2002).

${ }^{188}$ Id. at $311-12$.

${ }^{189}$ Id. at 312 (internal quotations omitted). Justice Stevens and the majority supported their "evolving standards" review of state legislative opinion with evidence that expert organizations, representatives of religious organizations, and world opinion opposed execution of offenders with mental retardation. Id. at 316 n.21. Recent U.S. polling data showing a consensus against these executions was also used to support the standard of decency analysis. Id. A plurality had relied on similar evidence to support a finding of legislative national consensus or standard of decency against executing those fifteen years of age or younger at the time of their crimes in Thompson v. Oklahoma, 487 U.S. 815, 830 (1988) (plurality opinion). The Court referenced international opinion in Trop v. Dulles, 356 U.S. 86, 102-103 (1958), Coker v. Georgia, 433 U.S. 584, 596 n.10 (1977), and Enmund v. Florida, 458 U.S. 782, 796-97 n.22 (1982). Two commentators have opined that reliance on such evidence makes the Court's evolving standards of decency analysis less objective. See Steiker \& Steiker, supra note 121, at 735.
} 
own judgment will be brought to bear on the question of the acceptability of the death penalty under the Eighth Amendment." "190 This turn of phrase, indicating that the Court will use its "own judgment" in applying the proportionality principle of the Eighth Amendment, has been the source of considerable and heated controversy among the justices. In Atkins itself, Justice Scalia, in dissent, ${ }^{191}$ repeated $^{192}$ his vehement objection to justices interpreting and applying the Eighth Amendment beyond the nose-counting of legislative enactments and jury decisions. His very heated rhetoric gives a flavor for the deep divide in the Court over these issues:

Beyond the empty talk of a "national consensus," the Court gives us a brief glimpse of what really underlies today's decision: pretension to a power confined neither by the moral sentiments originally enshrined in the Eighth Amendment (its original meaning) nor even by the current moral sentiments of the American people. "The Constitution," the Court says, "contemplates that in the end our own judgment will be brought to bear on the question of the acceptability of the death penalty under the Eighth Amendment." (The unexpressed reason for this unexpressed "contemplation" of the Constitution is presumably that really good lawyers have moral sentiments superior to those of the common herd, whether in 1791 or today.) The arrogance of this assumption of power takes one's breath away.... "In the end," it is the feelings and intuition of a majority of the Justices that count - "the perceptions of decency, or of penology, or of mercy, entertained ... by a majority of the small and unrepresentative segment of our society that sits on this Court." 193

But Justice Scalia refused to acknowledge that for more than a century pre-dating the Gregg three-justice plurality opinion that created the objective indicators, the Court approached Eighth Amendment questions in precisely the way he abhors and

\footnotetext{
${ }^{190}$ Atkins, 536 U.S. at 312 (quoting Coker v. Georgia, 433 U.S. 584, 597 (1977)).

191 Justice Scalia was joined by Chief Justice Rehnquist and Justice Thomas. Id. at 337 (Scalia, J., dissenting).

192 Justice Scalia voiced the same strident objections to this aspect of the analysis in Thompson $v$. Oklahoma, 487 U.S. 815, 873 (1988) (Scalia, J., dissenting); Stanford v. Kentucky, 492 U.S. 361, 378 79 (1989) (plurality opinion) (stating that "we emphatically reject [the] suggestion that the issues in this case permit us to apply our 'own informed judgment"'); Penry v. Lynaugh, 492 U.S. 302, 351 (1989) (stating that "I think this inquiry has no place in our Eighth Amendment jurisprudence"); and Roper v. Simmons, 543 U.S. 551, 607-08 (2005) (Scalia, J., dissenting) (stating that "[t]he Court ... proclaims itself sole arbiter of our Nation's moral standards" when it applies its own judgment to the Eighth Amendment question).

${ }^{193}$ Atkins, 536 U.S. at 348-49 (Scalia, J., dissenting) (quoting Coker, 433 U.S. at 597 (emphasis added) and Thompson v. Oklahoma, 487 U.S. 815, 873 (1988) (Scalia, J., dissenting)).
} 
U N I V E R S I T Y O F P I T T S B U R G H L A W R E V I E W

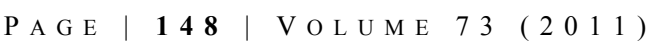

argues is wrong. And significantly, the Atkins opinion garnered a six-member majority ${ }^{194}$ when many death penalty decisions were only plurality opinions, ${ }^{195}$ suggesting strong support for employment of the Court's own judgment about excessiveness and human dignity.

Despite Justice Scalia's protests, a Court majority again emphasized excessiveness, proportionality, and human dignity in striking down the death penalty for juveniles in Roper $v$. Simmons. ${ }^{196}$ Justice Kennedy began the discussion with the following:

[T]he Eighth Amendment guarantees individuals the right not to be subjected to excessive sanctions. The right flows from the basic " "precept of justice that punishment for crime should be graduated and proportioned to [the] offense."” By protecting even those convicted of heinous crimes, the Eighth Amendment reaffirms the duty of the government to respect the dignity of all persons. ${ }^{197}$

He went on: "To implement this framework we have established the propriety and affirmed the necessity of referring to 'the evolving standards of decency that mark the progress of a maturing society' to determine which punishments are so disproportionate as to be cruel and unusual." ${ }^{, 198}$ In canvassing recent decisions applying the evolving standards analysis, he noted the objective, legislative evidence adduced in those cases but omitted the mantra of Coker that objective evidence should inform the evolving standards determination to the maximum possible extent. It is not an inconsequential omission; small shifts by the Court can have significant consequences for application of the Eighth Amendment. This shift away from Coker's heavy reliance on objective evidence places more emphasis on the "dignity of man" (or all persons) principle, the fundamental concept underlying the Amendment recognized since Reconstruction.

${ }^{194}$ See Atkins, 536 U.S. at 305.

${ }^{195}$ See, e.g., Stanford v. Kentucky, 492 U.S. 361 (1989) (plurality opinion); Thompson v. Oklahoma, 487 U.S. 815 (1988) (plurality opinion); Coker v. Georgia, 433 U.S. 584 (1977) (plurality opinion); Gregg v. Georgia, 428 U.S. 153 (1976) (plurality opinion).

${ }^{196} 543$ U.S. 551 (2005). For a discussion of Justice Kennedy’s and Justice Scalia's conflicting views of constitutional interpretation, at least in select contexts, see Lisa K. Parshall, Redefining Due Process Analysis: Justice Anthony M. Kennedy and the Concept of Emergent Rights, 69 ALB. L. Rev. 237 (2005).

${ }^{197}$ Roper, 543 U.S. at 560 (emphasis added).

${ }^{198} I d$. at $560-61$. 
Fleshing out the remainder of the Eighth Amendment construct, Justice Kennedy continued by recounting that in Atkins $v$. Virginia,

[t]he inquiry into our society's evolving standards of decency did not end [with the objective indicators].... Instead we returned to the rule, established in decisions predating Stanford, that the Constitution contemplates that in the end our own judgment will be brought to bear on the question of the acceptability of the death penalty under the Eighth Amendment. ${ }^{199}$

Justice Kennedy here seemed to more clearly emphasize the role of the Court in the excessiveness determination under the Eighth Amendment, returning in part, if subtly, to the historical approach before Gregg v. Georgia imposed the objective evidence requirement; before the Court stressed the primacy of the objective indicators; and before some members of the Court eschewed reliance on anything other than the objective legislative evidence. He would continue the reversion to basic principles in Kennedy v. Louisiana. ${ }^{200}$

\section{JUSTICE KENNEDY’s KENNEDY OPINION}

Kennedy presented an Eighth Amendment proportionality challenge to a capital sentence for rape of a child when the defendant did not kill or intend to kill the victim. ${ }^{201}$ In holding that the Eighth Amendment barred the death penalty for this crime, ${ }^{202}$ Justice Kennedy's opinion ${ }^{203}$ is startling in its expression of human dignity-based Eighth Amendment principles, stands in stark contrast to Gregg and some of the post-Gregg opinions that relied heavily on state legislatures, and goes even further than his opinion in Roper in shoring up Eighth Amendment protections. Justice Kennedy began by stating that the Amendment prohibits all excessive punishments, acknowledging the Weems $v$. United States statement that proportionality in punishment is a basic precept of justice. ${ }^{204}$ Right away, he placed emphasis on excessiveness, rather than on legislature-driven, evolving standards.

${ }^{199}$ Id. at 563 (emphasis added) (citations and internal quotation marks omitted).

${ }^{200}$ Kennedy v. Louisiana, 554 U.S. 407 (2008).

${ }^{201}$ Id. at $412-13$.

${ }^{202}$ Id. at 413.

${ }^{203}$ Justice Kennedy was writing for the Court, joined by Justices Stevens, Souter, Ginsburg, and Breyer. See id. at 410. Justice Alito dissented and was joined by Chief Justice Roberts and Justices Scalia and Thomas. See id.

${ }^{204} I d$. at 419 . 
U N I V E R S I T Y O F P I T T S B U R G H L A W R E V I E W

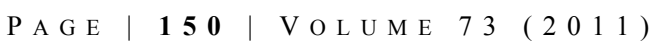

When next turning to the idea that " $[\mathrm{t}] \mathrm{he}$ Amendment 'draw[s] its meaning from the evolving standards of decency that mark the progress of a maturing society,", 205 he did not invoke the "maximum possible extent" language of Coker. Rather, he linked and subordinated the evolving standard to the dignity of man (now "dignity of all persons") principle underlying the Amendment and re-elevated it to its preeminent place in the interpretation of the Cruel and Unusual Punishments Clause: "Evolving standards of decency must embrace and express respect for the dignity of the person, and the punishment of criminals must conform to that rule. ${ }^{206}$ Unpacked, this statement requires that the punishment comport with the "dignity of man" principle; the evolving standard, including the legislative standard, of what is decent punishment must also comport with that principle. The upshot is that the "dignity of the person" concept has meaning on its own, and legislatures' standards of punishment must conform to that, rather than permitting legislative standards to be co-extensive with the dignity principle so as to play a dominant role in determining the extent of allowable punishment. Were legislative standards so significant as to constitute the measure of punishment, there would be little outside restraint on states' power to punish. The Eighth Amendment, infused with the idea that basic human dignity is to be respected, exists to provide the restraint against how the masses may want to punish, and the restraint is better achieved with a test that emphasizes human dignity than with a test that allows states themselves to provide the measure that is to limit them.

The ideal of respect for the dignity of the person underlying the Amendment also explains the Court's use of penological justifications for punishment as guides to excessiveness; presumably, if a punishment furthers recognized goals of punishment, it is less likely to be seen as too much punishment in the sense that the punishment is purposeless or unnecessary. As the Court had done on previous occasions, ${ }^{207}$ Justice Kennedy listed rehabilitation, deterrence, and retribution as justifications for punishment. ${ }^{208}$ Stunningly, he next stated:

\footnotetext{
${ }^{205} \mathrm{Id}$. (alteration in Kennedy).

${ }^{206} I d$. at 420 (emphasis added).

${ }^{207}$ See supra text accompanying notes 132-33; see also Stanford v. Kentucky, 492 U.S. 361, 403-05 (1989) (Brennan, J., dissenting); Penry v. Lynaugh, 492 U.S. 302, 335-36 (1989) (opinion of O'Connor, J.), abrogated by Atkins v. Virginia, 536 U.S. 204 (2002); Thompson v. Oklahoma, 487 U.S. 815, 83638 (1988) (plurality opinion); Enmund v. Florida, 458 U.S. 782, 798-800 (1982).

${ }^{208}$ Kennedy, 544 U.S. at 420.
} 
K E N N E Y , KENNEDY, A N D T H E E I G H H A M E N D E N T

\begin{tabular}{l|lll} 
P A G E & 151
\end{tabular}

It is the last of these, retribution, that most often can contradict the law's own ends. This is of particular concern when the Court interprets the meaning of the Eighth Amendment in capital cases. When the law punishes by death, it risks its own sudden descent into brutality, transgressing the constitutional commitment to decency and restraint. ${ }^{209}$

For this observer of Supreme Court Eighth Amendment death penalty decisions, the last sentence was startling because it was the first time the Court acknowledged the stark truth that death is an extreme, brutal punishment. In the past, some members have agreed that death is different than other punishments in its "severity and irrevocability" 210 but have come nowhere close to this recognition of what state killing of a human being really is. It seems that the Court finally grasped the Eighth Amendment problem with the death penalty: the Eighth Amendment embodies the founders' commitments to decency and restraint that could well be transgressed by a punishment as brutal as execution. The passage serves again to reestablish concern for human dignity and prohibition of brutality as the touchstones of Eight Amendment protection. The passage further infers that these touchstones can restrain states from imposing excessive punishments, despite their desire for retribution, because retribution can too easily take on a revenge quality in excess of what is necessary to achieve justifiable goals of punishment. In that way, retribution can contradict the law's own ends: achieving retribution within the bounds of the Eighth Amendment.

Because the human dignity limits on punishment are informed by the principal rationales for punishment, especially retribution, the Court asked whether the punishment is necessary to achieve retribution: "[W]e have explained that capital punishment must be limited to those offenders who commit 'a narrow category of the most serious crimes' and whose extreme culpability makes them 'the most deserving of execution.", 211 In other words, the retributive limit on capital punishment boils down to an excessiveness, or absolute proportionality, analysis, weighing the severity of the punishment against the seriousness of the crime, which also includes considering the culpability of the offender. In concluding the point about dignity and excessiveness, Justice Kennedy stated that

\footnotetext{
${ }^{209} I d$. (emphasis added).

${ }^{210}$ See, e.g., Gregg v. Georgia, 428 U.S. 153, 187 (1976) (plurality opinion); Coker v. Georgia, 433 U.S. 584, 598 (1977).

${ }^{211}$ Kennedy, 554 U.S. 420 (quoting Roper v. Simmons, 543 U.S. 551, 568 (2005) (quoting Atkins v. Virginia, 536 U.S. 304, 319 (2002)) (internal quotation marks omitted).
} 
U N I V E R S I T Y O F P I T T S B U R G H L A W R E V I E W

PAGE

"the Court insists upon confining the instances in which the punishment can be imposed," 212 signaling that it is the Court that applies the absolute proportionality principle. In this, Justice Kennedy was reasserting first principles, with an emphasis on the Court's own assessment of what constitutes too much punishment for human dignity.

When Justice Kennedy finally brought in the "objective" indicators of standards of decency, he did not revive the "maximum possible extent" language of the post-Gregg and pre-Atkins cases. Rather, he arguably downplayed their significance, stating that "[i]n these cases the Court has been guided by objective indicia of society's standards, as expressed in legislative enactments and state practice with respect to executions." 213 The shift in tone is subtle but part of the whole emphasis toward the Court's own excessiveness analysis under the "dignity of the person" standard. It is true that at points he did indicate that the proportionality analysis "depends" in part on consensus, ${ }^{214}$ that "objective evidence of contemporary values . . is entitled to great weight," 215 and that the decision was "[b]ased both on consensus and our own independent judgment ...."216 But although he used the precedential words, his emphasis was on "the Court's own understanding and interpretation of the Eighth Amendment's text, history, meaning, and purpose." 217 Later in the opinion, repeating that the "Constitution contemplates that in the end our own judgment will be brought to bear on the question of the acceptability of the death penalty under the Eighth Amendment,",218 Justice Kennedy next stated, "[w]e turn, then, to the resolution of the question before us, which is informed by our precedents and our own understanding of the Constitution and the rights it secures." ${ }^{219}$ His chosen language reveals his posture toward these cases, which is that the Court resolves the Eighth Amendment proportionality question, not legislatures. $^{220}$

\footnotetext{
${ }^{212} I d$. (emphasis added).

${ }^{213} I d$. at 421 (internal quotation marks omitted).

${ }^{214} I d$.

${ }^{215} I d$. at 434.

${ }^{216} I d$. at 421 .

${ }^{217} I d$.

${ }^{218}$ Id. at 434 (quoting Coker v. Georgia, 433 U.S. 584, 597 (1977)).

${ }^{219} I d$. (emphasis added).

${ }^{220}$ His approach in this regard was similar in Roper v. Simmons, 543 U.S. 551 (2005), which evaluated an Eighth Amendment disproportionality challenge to the execution of juveniles. He made clear in
} 
In resolving the question, Justice Kennedy returned to the basic principles underlying the Amendment, and his statements strikingly rival those in many postGregg cases in their focus on first principles. Rather than simply counting legislative noses, as Justice Scalia and a few other justices would do to resolve these questions, Justice Kennedy reverted to the purpose of the Amendment to determine whether execution of child rapists transgresses the Amendment. Following the earliest cases, Justice Kennedy did not isolate the evolving standards of decency, treating those standards as determined primarily by legislative action; rather, and consistent with his statement at the beginning of the case, he subsumed the evolving standards of decency under the Court's "own judgment" analysis. ${ }^{221}$ This approach signaled that the Court also ultimately determines the evolving standard, not legislatures or juries. Restating that a state's punishment power is bounded by "the limits of civilized standards," 222 Kennedy next asserted that "evolving standards of decency ... counsel us to be most hesitant before interpreting the Eighth Amendment to allow the extension of the death penalty .... It is an established principle that decency, in its essence, presumes respect for the individual and thus moderation or restraint in the application of capital punishment." ${ }^{223}$ Justice Kennedy here clearly recognized an objective valuation of decency independent of popular will. In addition, he also linked that objective

Roper that state practice or legislative enactments provided a guide, a starting point on the proportionality question, but in the end the decision on proportionality was for the Court:

The inquiry into our society's evolving standards of decency [in Atkins v. Virginia, 536 U.S. 304 (2002)] did not end [with the evidence of state practice]. The Atkins Court neither repeated nor relied upon the statement in Stanford [v. Kentucky, 492 U.S. 361 (1989)] that the Court's independent judgment has no bearing on the acceptability of a particular punishment under the Eighth Amendment. Instead we returned to the rule, established in decisions predating Stanford, that the Constitution contemplates that in the end our own judgment will be brought to bear on the question of the acceptability of the death penalty under the Eighth Amendment. . . .

...

The beginning point is a review of objective indicia of consensus, as expressed in particular by the enactments of legislatures that have addressed the question. These data give us essential instruction. We then must determine, in the exercise of our own independent judgment, whether the death penalty is a disproportionate punishment for juveniles.

Id. at 563-64 (emphasis added) (internal quotation marks omitted).

${ }^{221}$ Kennedy, 554 U.S. at 461.

${ }^{222}$ Id. at 435 (quoting Trop v. Dulles, 356 U.S. 86, 100 (1958) (plurality opinion)).

${ }^{223} I d$. 
valuation of decency with the basic idea underlying the Eighth Amendment: the dignity of all persons. From the "dignity of all persons" principle, to the evolving standard of decency, to the consequent restraint on the power to punish by death, Justice Kennedy reestablished the protection afforded individuals by the Eighth Amendment against state legislatures and mob mentality. Applying those principles, the Court restrained use of the death penalty in non-homicide crimes like child rape. ${ }^{224}$

In supporting his conclusion, Justice Kennedy further noted that it is already difficult to develop standards to confine use of the death penalty in murder cases, but the difficulty is tolerated because a victim has died. ${ }^{225}$ The Court, in the voice of Justice Kennedy, was not willing to import that difficulty into child rape cases, allowing for a much expanded death penalty, when no death of a victim had occurred: "Evolving standards of decency are difficult to reconcile with a regime that seeks to expand the death penalty to an area where standards to confine its use are indefinite and obscure." 226 In other words, the evolving standard that seeks to restrain the death penalty out of respect for the dignity of the person will not tolerate expansion to another crime that could result in even more expansion because of a lack of narrowing or confining standards.

The foregoing discussion was based on nothing more than the Court's judgment about the essential principles animating the Eighth Amendment, which is wholly consistent with the earliest precedents. But the Court went further in assessing proportionality, measuring excessiveness with the yardsticks of penological justification: retribution and deterrence. ${ }^{227}$ And in this analysis the justices must also use their own judgment to evaluate how the punishment stacks up against these punishment rationales.

Addressing the rationales, Justice Kennedy wrote that it is not certain that the death penalty for child rape serves no retributive or deterrent function, but he also identified related concerns that nonetheless counseled against expanding the death penalty in this way, particularly because the "incongruity between the crime of child rape and the harshness of the death penalty poses risks of overpunishment ...."228 In this, Justice Kennedy was making an absolute proportionality

\footnotetext{
${ }^{224}$ Id. at 438 .

${ }^{225} I d$. at 439.

${ }^{226} I d$. at 441 .

${ }^{227} I d$.

${ }^{228} I d$.
} 
observation, finding incongruous the seriousness of the crime and the severity of the punishment; that mismatch risked too much punishment, a classic proportionality analysis under the Eighth Amendment. This analysis is also consistent with his 1991 opinion in the non-capital case of Harmelin $v$. Michigan. ${ }^{229}$ In Harmelin, Justice Kennedy said that proportionality under the Eighth Amendment should be judged by three "objective" factors, which required assessment of the severity of the penalty in relation to the seriousness of the crime, intra-jurisdictional comparative analyses of crimes and sentences, and interjurisdictional comparative analysis concerning the same crime. ${ }^{230}$ The last two, in his view, need only be conducted if the first raised an inference of gross proportionality. ${ }^{231}$ In Kennedy, Justice Kennedy approached the question of proportionality between the severity of the punishment and the seriousness of the crime as an objective determination that the Court could decide. The Kennedy Court also conducted an inter-jurisdictional comparative analysis but found very few states punishing child rape with death. ${ }^{232}$ So, not only was Justice Kennedy's approach consistent with first principles illustrated in the earliest cases, but it is also clear his thinking developed along those lines as far back as the non-capital Harmelin case.

But Justice Kennedy had more reasons to find disproportionality beyond the Eighth Amendment's principle of restraint and the Court's incongruity finding. Because there was a risk of too much punishment, other difficulties with the achievement of retribution and deterrence led further to a conclusion of excessiveness. Probably foremost and most generally, Justice Kennedy opined that depraved murder, which could justify capital punishment as retribution, simply does not compare to child rape: "The goal of retribution ... does not justify the harshness of the death penalty here. ${ }^{, 233}$ Again, the Court conveyed its sense of too much punishment. In addition, Justice Kennedy observed, it is not clear that a sentence of death balances the wrong to the child rape victim, considering that the victim, in formative childhood years, must be a major participant in the state's attempts at obtaining a death sentence. ${ }^{234}$ As Justice Kennedy noted,

\footnotetext{
${ }^{229} 501$ U.S. 957, 996 (1991) (Kennedy, J., concurring in part and concurring in the judgment).

${ }^{230}$ See id. at $1004-05$.

${ }^{231} I d$. at 1005.

${ }^{232}$ Kennedy, 554 U.S. at $432-34$.

${ }^{233} I d$.

${ }^{234} I d$. at 435 .
} 
U N I V E R I T Y OF P I T T S B U R G H L A W R E V I E W

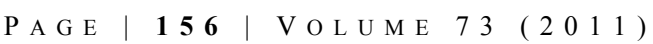

[s]ociety's desire to inflict the death penalty for child rape by enlisting the child victim to assist it over the course of years in asking for capital punishment forces a moral choice on the child, who is not of mature age to make that choice. The way the death penalty here involves the child victim in its enforcement can compromise a decent legal system .... ${ }^{235}$

Although Justice Kennedy did not explicitly do so, this last point can be tied back in to the Eighth Amendment's principle of restraint of punishments sought by the masses. Voters who elect legislators who in turn push for the death penalty for child rapists are all adults who may not consider the grueling task forced on child rape victims by requiring them to participate in the pursuit of the death penalty. Restraint counsels against such enlistment when children are involved.

Justice Kennedy also identified "serious systemic concerns" relevant to the Eighth Amendment question in this case. ${ }^{236}$ As did Justice Stevens in Atkins v. Virginia, ${ }^{237}$ Justice Kennedy identified the "special risk of wrongful execution" in child rape cases that depend on child testimony, which in some cases can be easily induced or created. ${ }^{238}$ The risk of wrongful executions is high enough that it "undermines, at least to some degree, the meaningful contribution of the death penalty to legitimate goals of punishment." 239 The risk is that some death sentences will be erroneously imposed, will not achieve retribution, and therefore will result in obviously too much punishment. In the end, Justice Kennedy wrote that the legislatures' judgment to achieve retribution using capital punishment had to be weighed against this special risk. ${ }^{240}$ That the Court weighed and considered these factors in assessing excessiveness under the Eighth Amendment is entirely appropriate and within the scope of its historical, constitutional responsibility to judge whether punishment is excessive.

In addressing the deterrence justification for the death penalty in child rape cases, Justice Kennedy similarly found achievement of this penological goal less likely because of the risks of underreporting, which is common in child sex abuse

\footnotetext{
${ }^{235}$ Id. at 443.

${ }^{236} I d$.

${ }^{237}$ See 536 U.S. 304, 320-21 (2002).

${ }^{238}$ Kennedy, 554 U.S. at 443.

${ }^{239} I d$.

${ }^{240}$ Id. at 444.
} 
cases. ${ }^{241}$ In addition, because of the risk that a harsh penalty like death could actually encourage child rapists to kill their victims, thereby having an opposite deterrent effect, the argument for death was not as compelling as for murders. ${ }^{242}$ Taken with the other difficulties posed by the punishment in these cases, the problems with the deterrence justification added to the "serious negative consequences of making child rape a capital offense." ${ }^{243}$ For all of the reasons identified by the Court, it concluded that the death penalty is too much punishment for child rape, excessive, and not a proportional punishment for that crime. ${ }^{244}$

Like some prior opinions, Justice Kennedy's opinion addressed anticipated criticisms of its holding and use of its "own judgment" but took an approach that differed in tone from previous Court justifications of its role; some of those explanations arguably smacked of apology for the very application of the Eighth Amendment as the Court saw it. For example, in striking down an enactment on cruel and unusual punishment grounds, the Court in Weems v. United States stated,

prominence is given to the power of the legislature to define crimes and their punishment. We concede the power in most of its exercises. We disclaim the right to assert a judgment against that of the legislature of the expediency of the laws or the right to oppose the judicial power to the legislative power to define crimes and fix their punishment, unless that power encounters in its exercise a constitutional prohibition. In such case not our discretion but our legal duty, strictly defined and imperative in its direction, is invoked. Then the legislative power is brought to the judgment of a power superior to it for the instant.... However, there is a certain subordination of the judiciary to the legislature. The function of the legislature is primary, its exercises fortified by presumptions of right and legality, and is not to be interfered with lightly, nor by any judicial conception of their wisdom or propriety. They have no limitation, we repeat, but constitutional ones, and what those are the judiciary must judge. We have expressed these elementary truths to avoid the misapprehension that we do not recognize to the fullest the wide range of power that the legislature possesses to adapt its penal laws to conditions as they may exist and punish the crimes of

\footnotetext{
${ }^{241} I d$. at $444-45$.

${ }^{242}$ Id. at 445 .

${ }^{243} I d$. at 446 .

${ }^{244}$ Id. at $446-47$.
} 
U N I V E R I T Y OF P I T T S B U R G H L A W R E V I E W

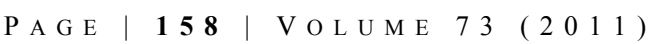

men according to their forms and frequency. We do not intend in this opinion to express anything that contravenes those propositions. ${ }^{245}$

One senses a similar defensiveness in Trop v. Dulles, when the Court struck down an act of Congress, again on Eighth Amendment grounds:

\begin{abstract}
When it appears that an Act of Congress conflicts with one of these [constitutional] provisions, we have no choice but to enforce the paramount commands of the Constitution. We are sworn to do no less. We cannot push back the limits of the Constitution merely to accommodate challenged legislation. We must apply those limits as the Constitution prescribes them, bearing in mind both the broad scope of legislative discretion and the ultimate responsibility of constitutional adjudication. We do well to approach this task cautiously, as all our predecessors have counseled. But the ordeal of judgment cannot be shirked. ${ }^{246}$
\end{abstract}

In these cases the Court explained its constitutional authority to respond to anticipated critics disturbed by the Court's striking of a legislative enactment, seemingly feeling the need to justify applying a constitutional provision.

In Kennedy, Justice Kennedy provided an unapologetic and more forceful response to anticipated criticisms. The specific criticisms he expected were that by simply addressing the Eighth Amendment question around the death penalty for child rape, the Court was improperly interfering with the evolving standardsmaking process; that by restraining states from this punishment, it was preventing the emergence of consensus regarding death for child rape; and that by barring the punishment, "[t]he Court ... itself [became] enmeshed in the process, part judge and part maker of that which it judges. ${ }^{.247}$ In effect, the argument he expected was the familiar one, accusing the Court of making policy based on its own predilections of what is decent and therefore what should be the evolving standard, in the guise of interpreting the Eighth Amendment. His defense to the criticism emanated from first principles of the Eighth Amendment, which ultimately derive from the dignity of all persons ideal. In his and the Court's view, the criticisms

\footnotetext{
${ }^{245} 217$ U.S. $349,378-79$ (1910).

${ }^{246} 356$ U.S. 86, 104 (1958).

${ }^{247} 554$ U.S. at 446.
} 
overlook the meaning and the full substance of the established proposition that the Eighth Amendment is defined by the evolving standards of decency that mark the progress of a maturing society. Confirmed by repeated, consistent rulings of this Court, this principle requires that use of the death penalty be restrained. The rule of evolving standards of decency with specific marks on the way to full progress and mature judgment means that resort to the penalty must be reserved for the worst of crimes and limited in its instances of application. ${ }^{248}$

This parting passage, identifying an independent principle of restraint in the evolving standard of decency, caps off Justice Kennedy's restoration of the earliest interpretations of the Eighth Amendment, which found in the Amendment's prohibition of cruel and unusual punishments the fundamental principle of respect for the dignity of all persons. From very early on, the Justices conveyed their perceptions and beliefs that legislatures could impose too much punishment, or excessive punishment, that was not proportional to the crime committed. Excessive punishments could be identified through the evolving standard of decency, which could be guided by what legislatures were doing but ultimately had a basic meaning of its own. When earlier Courts concluded that punishments were simply excessive or not proportional to the crime committed, they were recognizing a principle of restraint embodied in the standard of decency, in the prohibition of excessive punishments, and in the principle that respects the dignity of all persons, apart from the practices of state legislatures. It is a recognition that the Eighth Amendment provided a restraint that state governments might not impose upon themselves. And that recognition and enforcement of the Eighth Amendment is the Court's right and responsibility under the Constitution. Justice Kennedy's unapologetic reassertion of that right and exercise of that responsibility in Kennedy followed in tradition when he concluded that there is a basic principle of restraint that counsels against expanded use of the death penalty for a crime that is not among the worst — not as serious as murder. ${ }^{249}$ He made clear that the restraint exists as a part of the evolving standard and informs its meaning separately from state practice as shown by legislative enactments. Thus, one can find in his Kennedy opinion the threads of the earliest cases, and these threads provide a unifying principle: respect for the dignity of all persons, a respect that must be guarded independently of the consensus of state legislatures.

\footnotetext{
${ }^{248} I d$. at 446-47 (emphasis added) (internal quotation marks omitted).

${ }^{249}$ Id. at 435-36.
} 
U N I V E R I T Y OF P I T T S B U R G H L A W R E V I E W

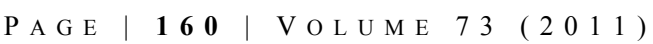

\section{Conclusion}

The thread of respect for dignity of the person unifies the Supreme Court's opinions interpreting or applying the Eighth Amendment's Cruel and Unusual Punishments Clause over the last 150 years. The thread carries with it the principle of restraint in punishment, limiting state legislatures whenever they seek to punish and especially when they seek to punish with death. That restraint ideal manifests itself in the requirement that punishments not be excessive but rather proportional to the culpability of the offender or seriousness of the crime. Because history is filled with punishments that we now consider excessive even though the people, through their legislative representatives, wanted them, legislative enactments should not be considered a defining aspect of excessiveness or proportionality under the Eighth Amendment. The Eighth Amendment provides an individual right against and an overarching restraint on that mob approach to punishment, and someone must say when mob punishment is excessive or not proportional. Under our Constitution, that someone is the Court. In applying the Eighth Amendment, as when applying any clause of the Constitution, the Court is simply doing its job:

That the task of interpreting the great, sweeping clauses of the Constitution ultimately falls to us has been for some time an accepted principle of American jurisprudence. See Marbury v. Madison, 1 Cranch 137, 177 (1803) ("It is emphatically the province and duty of the judicial department to say what the law is"). With the Eighth Amendment, whose broad, vague terms do not yield to a mechanical parsing, the method is no different. ${ }^{250}$

Therefore, the Court should look at current legislative standards as a guide to the standard of decency or level of restraint required, but Eighth Amendment proportionality review should not be "informed ... to the maximum possible extent" ${ }^{251}$ by legislative enactments or state practice. Rather, in order for the Amendment to remain a bulwark against excessive punishment of individuals and a critical protection of the Bill of Rights, the Court should use its own judgment to determine whether a state punishment has exceeded the bounds of decency and restraint imposed by the respect for human dignity underlying the Eighth Amendment's Cruel and Unusual Punishments Clause.

\footnotetext{
${ }^{250}$ Thompson v. Oklahoma, 487 U.S. 815, 833 n.40 (1988) (plurality opinion).

${ }^{251}$ Coker v. Georgia, 433 U.S. 584, 592 (1977) (plurality opinion).
} 